\title{
Understanding the expansion of oil palm cultivation: A case-study in Papua
}

\author{
Pablo Acosta, María Dolores Curt
}

\begin{abstract}
A B S T R A C T
The overall objective of this article is to understand the reasons underlying the expansion of oil palm plantations in forested land, as well as to define ways to improve business as usual practices in Indonesia. In order to do so, a case study is addressed in a recently established oil palm plantation in Papua, Indonesia. Based on field work and literature data a cost benefit analysis comparing the benefits of the original primary forest land use to those of the newly established oil palm plantation was conducted. It was shown that development is important to local population; oil palm plantations can bring wealth and improved living standards, but establishment on forested areas also takes a lot of value away due to the loss of ecosystem services. The benefits from primary forest ecosystem services were estimated at 3,795.44 USD ha ${ }^{-1} \mathrm{y}^{-1}$ while the profits estimated for the new established oil plantation were 2,153.00 USD ha ${ }^{-1} \mathrm{y}^{-1}$, therefore the land use change was not feasible. When running sensitivity analysis, it was revealed that prices of carbon emissions and commodities (Crude Palm Oil and Kernel Oil) have a large impact on the results. The beneficiaries are changing due to land use change, being the local population the biggest loser and the plantation company the biggest winner. Benefits are transferred from the local and global level to the national level. Case to case feasibility analysis including economic, environmental and social aspects should be required in advance to decide on the approval of an oil palm project.
\end{abstract}

\section{Introduction}

Indonesia is a developing country with GDP of 3,400 USD per capita and total population of 261.12 million in 2016, equivalent to 144 persons per $\mathrm{km}^{2}$ population density (The World Bank, 2016a); $73 \%$ of the population is concentrated in only two islands (Java and Sumatra), while the country is composed of about 17,504 islands (Indonesia, 2017). Between 1960 and 2016 Indonesian population increased three-fold (The World Bank, 2016b), resulting in higher pressure on natural resources. Indonesia lost $23.23 \%$ of forested area in the period 1990-2015, compared to a loss of only $3.13 \%$ of forested area worldwide. According to Vijay et al. (2016) annual global carbon emissions from gross tropical deforestation contributes nearly $10 \%$ to total anthropogenic greenhouse gas emissions.

Palm oil represents $17 \%$ of total agricultural revenues, making it the most important agricultural product of Indonesia. In 2016 palm oil represented 2.36\% of Indonesia's GDP (The World Bank, 2016a; Indonesia Investments, 2017). Indonesia is currently expanding its palm oil industry due to its apparently positive economic impact, contribution to an increase in GDP and national development. The Palm Oil Industry in Indonesia meets the four attributes of national competitive advantage (Porter, 1990), blending into an environment that allows international success. Caroko et al. (2011) reported that Indonesia possessed about 27 Mha of 'unproductive forestlands' that could be potentially converted into plantations. Nowadays, the main target for new concessions of oil palm is eastern Indonesia.

Papua is an eastern region of Indonesia, rich in natural resources but highly undeveloped, that occupies the west part of New Guinea Island. About $657,000 \mathrm{~km}^{2}$ of the Guinea Island ( $82 \%$ area) was forested in 2000. It is considered one of the three world low land tropical forest wilderness areas. Forests in low lands are climax forests and have many types of trees and plant species that are only present on New Guinea island; some of the species of flora and fauna have yet to be discovered (Beehler and Marshall, 2007). This region has claimed independence from Indonesia in the last years; the central government is trying to develop this region. Monetary transfers from Jakarta to Papua have grown about $1300 \%$ in nominal terms and 600\% in real terms from 2000 to 2009 (The World Bank, 
2009a).

As new oil palm plantations are established in Papua, new infrastructures are developed, allowing for more rapid development of the local communities (Andrianto et al., 2014). However, at the same time, plantations destroy the natural ecosystem and the services related to it; access to timber is lost for the local population and forestry activities concentrate in areas nearby (Obidzinski et al., 2014). Further pressure is put in remaining forests and land conflicts disrupt plantations and conservation efforts (Meijaard et al., 2018). In certain cases conflicts arise during oil palm plantation establishment; Abram et al. (2017) quoted that forest land-use related conflicts affected 12.3-19.6 million people in the period 1990-2000. If Papua followed the luck of other islands of Indonesia, few forests in Papua would remain at the end of the century (Beehler and Marshall, 2007).

However, palm oil affects positively the employment in rural areas. Oil palm can represent $63 \%$ of smallholder household incomes, and 22,000-120,000 employment opportunities have been created in East Kalimantan Province (Irawan et al., 2013). Despite this fact, not always the local population can benefit from the plantation job opportunities. Andrianto et al. (2014) stated that two thirds of the jobs were unskilled and temporal jobs at Papua Boven Digoel District plantations; most of the skilled jobs were taken by immigrant workers whereas the unskilled ones were taken by Papuans. According to Obidzinski et al. (2012), many Papuans cannot access the jobs in the plantations as they are not skilled enough for that; additionally, they are not willing to give up their traditional way of life.

At present, there is a great controversy about oil palm expansion in Indonesia. On the one hand, oil palm generates prosperity, increase in GDP and country growth, production of biofuels, jobs creation, establishment of services and infrastructures. On the other hand, if plantations are not established sustainably, they can bring negative effects such as deforestation, GHG emissions, loss of ecosystem services, pollution and loss of living habitat for the local population. Previous studies tried to assess the problem of oil palm new plantations in Papua in a qualitative way but the value of forest ecosystem services in this region remains unknown. Economic and social benefits brought by new plantations, as well as their distribution, need to be determined. It is of critical importance to quantify if benefits are higher than losses, and to find ways to improve the conversion process.

The overall objective of this study is to assess the economic, environmental and social feasibility of transforming primary tropical forest to an oil palm (Elaeis guieenensis Jacq.) plantation. Global and local effects are studied through a case study of a newly established oil palm plantation established in primary forested land in Jayapura Regency, Papua Province, Indonesia, in order to assess if this change in land use makes sense. To answer this question a costbenefit financial model is developed based on information gathered in site visits and survey and literature data; benefits generated from the oil palm plantation are compared to those of the forest being replaced. Other objectives of this work include: knowing the opinion of Papuan population regarding new palm plantation establishment, understanding the positive and negative effects of the plantation establishment on forested land, and who is winning and losing in the process of land use conversion.

\section{Materials and Methods}

\subsection{Location, site visit and survey}

The newly established oil palm plantation: PT Rimba Matoa Lestari (PT RML) located in Jayapura Province of Indonesia $\left(2^{\circ} 27^{\prime}\right.$ $41.03^{\prime \prime}$ S, $139^{\circ} 55^{\prime} 34.89$ " E; 37 m.a.s.l.) was chosen for this study.
The original land condition was primary untouched climax tropical forest in Papua Island, being transformed to oil palm. Information on the value of the forest ecosystem services and on the oil palm plantation establishment was gathered from structured surveys to local population and from the company staff during a site visit conducted in December 2016.

The survey was designed starting with questions about the plantation established in the area, the original use of the plantation as well as the process for plantation establishment. In addition, the respondents were asked to explain if land had been allocated to local people. According to Indonesian law (Ministry of Agriculture of Indonesia, 2013) $20 \%$ of the total land has to be handed over to the local population. The second part of the survey asked participants to rate their perception about oil palm plantations. The third part of the survey required participants to answer if they worked at the plantation and, if they did, what level of income they could earn from it. The fourth part of the survey asks participants to name the negative effects of the oil palm plantation, their relationship with the forest and the benefits obtained from it. Boxes were prepared at each question for participants to choose from, and additional space was given below so that participants could share their thoughts. Participants were requested to choose the level of income derived from the forest, both for provisioning services and for non-tangible ecosystem services such as leisure and wellbeing. Boxes with different ranges of income were prepared in the survey in order to obtain standardized results that can be statistically analyzed.

The survey was conducted for 5 days, at PT RML plantation and the villages surrounding it. A total of 26 people were interviewed, obtaining a total of 24 valid responses; $87 \%$ were male and $13 \%$ female. Regarding age, $18 \%$ of participants were between 10 and 20 years of age, 32\% between 21 and 30 years of age, 15\% between 31 and $40,23 \%$ between 41 and 55 years of age and $14 \%$ above 65 years of age. In terms of income $32 \%$ of the participants declared an income below 500 thousand IDR, 32\% an income between one and two million IDR, 26\% between 2 and 3 million IDR and 5\% above 3 million IDR. Highest income rates came from plantation employees.

The people interviewed had different origins including: locals (53\%), regional (21\%) and trans-migrant (26\%); and different occupations: hunters/farmers (42\%), plantation workers (21\%), land owners (16\%), local village government officials (5\%) and woodcutters (5\%); unemployed (11\%) were also interviewed. Selection of the participants was random, going to their houses, churches, businesses as well as by approaching them in the street close to the plantation. The plantation was visited several times during this visit and PT RML staff was interviewed regarding the process of plantation establishment, government approvals, transformation process as well as costs and economics.

In order to generate grounded theory (Glaser and Strauss, 1967) previous existing literature on the subject, such as Andrianto et al. (2014) and Obidzinski et al. (2012), were reviewed. Our study tried to account for the benefits and costs produced by the plantation establishment, in order to assess its feasibility. Therefore, the survey was designed in order to collect quantitative data on the monetary values of provisioning ecosystem services provided by the forest to the local population. These data, combined with secondary data, were used to obtain the value of forest ecosystem services. In addition, qualitative information on oil palm benefits, such as access to jobs, infrastructures, health and education, as well as on issues such as deforestation or loss of access to forest products in previous studies, were verified by the survey.

\subsection{Methodology for the economic model}

\subsubsection{Methodology for the oil palm plantation}

Economics of the oil palm plantation were studied over the 
commercial lifespan of the plantation, from the first step involving the conversion of forest into agricultural land up to the palm oil sale final step. Assumptions and supporting information for this economic assessment are given in Table 1.

Financial results of this case study were determined in terms of return on investment (ROI), internal rate of return (IRR), repayment period, earnings before tax, average yearly earnings and discounted earnings. The weighted average cost of capital (WACC) in Indonesia was calculated as the weighted sum of the cost of equity (COE) and the cost of debt (COD), from the values of the interest rate $6.5 \%$ (Bank of Indonesia, 2016), inflation in 2016, 3.02\% (Triami Media, 2016), and national growth in 2016, 5.02\% (Indonesia Investments, 2017). These values were used to calculate a $10 \%$ discount rate. Taxes distribution at the national, regional and district levels were assessed as well.

\subsubsection{Methodology for social benefits brought by the plantation}

Oil palm plantations can bring social benefits to local population in terms of health, education and infrastructures. In our case-ofstudy these benefits were calculated as follows:

Health: Bloom et al. (2004) estimated that longevity contributed to a $4 \%$ in output. According to that, the social benefit associated with health was assessed by increasing the GDP per capita of the population living close to the plantation. This value was expressed per ha from the data of population living close to the plantation and at the plantation area.

Infrastructures: According to Ansar et al. (2017) the benefit to cost ratio of infrastructures investments falls below 1.0. A value of 1 was used for this study. The value of infrastructures from the plantation was taken from Svatonová et al. (2015). The value of this investment was allocated to the first five years and it was assigned as a social benefit in the model.

Table 1

Working data and supporting information on the values assumed for the economic assessment of the plantation.

\begin{tabular}{|c|c|c|}
\hline Working data for the economic model & Value & Supporting information \\
\hline \multicolumn{3}{|l|}{ Economic assumptions } \\
\hline Exchange rate (IDR per USD) ${ }^{\mathrm{a}}$ & 13,400 & $\mathrm{XE}$, rounded value. \\
\hline Discount Rate Commercial & $10 \%$ & Irawan et al. (2013) \\
\hline Discount Rate Social & $5 \%$ & $\begin{array}{l}\text { Irawan et al. (2013); Pascual et al. (2010); Gowdy et al. } \\
\text { (2010) }\end{array}$ \\
\hline Duration of the cycle & 25 years & Commercial lifespan of the plantation \\
\hline Area for study & 28,000 ha & $\begin{array}{l}\text { Yayasan Pusaka (2015); Personal communication with } \\
\text { company staff. }\end{array}$ \\
\hline Increase in Revenue Prices per year & $3 \%$ & Based on Indonesian inflation rate \\
\hline Increase in Price of Materials per year & $3 \%$ & Based on Indonesian inflation rate \\
\hline Increase in Operational Cost per year & $3 \%$ & Based on Indonesian inflation rate \\
\hline Increase in value of ecosystem services & $1 \%$ & Gowdy et al. (2010) \\
\hline $\begin{array}{l}\text { Interest Rate for Money Borrowing for Plantation in IDR currency assuming all } \\
\text { investment is borrowed }\end{array}$ & $7 \%$ & $\begin{array}{l}\text { Indonesia ( } 2016) \text {; June } 2016-6.5 \%+0.5 \% \text { commercial } \\
\text { bank mark up }\end{array}$ \\
\hline \multicolumn{3}{|l|}{ Manpower costs } \\
\hline Manpower Cost increase per year & $4 \%$ & Long term - 25 year period assumption \\
\hline Annual cost of 1 worker & $30,000,000$ IDR $^{-1}$ & PT RML staff information \\
\hline Workers per ha & 0.34 persons per ha & Svatonová et al. (2015) \\
\hline Local cost of labor (IDR) & $10,187,259$ IDR ha $^{-1}$ & salaries from site survey \\
\hline Cost of labor (USD) & $1,432.84$ USD ha $^{-1}$ & \\
\hline \multicolumn{3}{|l|}{ Timber revenue and development cost assumptions } \\
\hline Compensation for wood in Papua when removing forest & $50,000 \mathrm{IDR} \mathrm{m}^{-3}$ & Andrianto et al. (2014) \\
\hline Price of wood & $600,000 \mathrm{IDR} \mathrm{m}^{-3}$ & Andrianto et al. (2014) \\
\hline Production of wood & $17.58 \mathrm{~m}^{3} \mathrm{ha}^{-1}$ & Andrianto et al. (2014) \\
\hline Profit from wood cutting & 786.97 USD ha $^{-1}$ & Andrianto et al. (2014) \\
\hline Development cost & $3,731.34$ USD ha $^{-1}$ & Communication with PT RML staff \\
\hline \multicolumn{3}{|l|}{ Transport and refining costs and revenues } \\
\hline Transport to Mill & 96 USD ha $^{-1}$ & International Trade Centre (2012) \\
\hline Refining cost palm oil & 10 USD t $^{-1}$ & Man and Baharum (2011) \\
\hline Price of Crude Palm Oil (CPO) & 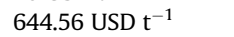 & Indexmundi (2016a) \\
\hline Price of Kernel Oil (KO) & 1,230 USD t $^{-1}$ & Indexmundi (2016b) \\
\hline Production of $\mathrm{CPO}$ & $4.55 \mathrm{tha}^{-1}$ & Svatonová et al. (2015) \\
\hline Production of KO & $0.90 \mathrm{tha}^{-1}$ & Svatonová et al. (2015) \\
\hline Percentage of CPO on Fresh Fruit Bunch (FFB) & $23.25 \%$ & Andrianto et al. (2014) \\
\hline Percentage Kernel Oil on FFB & $4.61 \%$ & Andrianto et al. (2014) \\
\hline CPO to kernel weight ratio & $19.83 \%$ & Svatonová et al. (2015) \\
\hline \multicolumn{3}{|l|}{ Recurrent costs } \\
\hline Land cost & 149.25 USD ha U $^{-1}$ & Communication with PT RML staff \\
\hline Cost of land conversion to oil palm & $3,731.34$ USD ha $^{-1}$ & Communication with PT RML staff \\
\hline Costs of agricultural operations & $\begin{array}{l}\text { Linear with the } \\
\text { production }\end{array}$ & Function developed from Svatonová et al. (2015) \\
\hline \multicolumn{3}{|l|}{ Taxes } \\
\hline Land value tax & $40 \%$ & Irawan et al. (2013) \\
\hline Vehicle, heavy machinery and equipment's taxes & $5 \%$ & $\begin{array}{l}\text { Irawan et al. (2013); equipment value from Svatonová } \\
\text { et al. (2015) }\end{array}$ \\
\hline Corporate income tax & $28 \%$ & Government tax official in Papua; personal interview. \\
\hline VAT & $10 \%$ & Indonesian market \\
\hline Personal income tax over plantation salaries & $10 \%$ & $\begin{array}{l}\text { Irawan et al. (2013); cost of salaries from Svatonová et al. } \\
\text { (2015) }\end{array}$ \\
\hline
\end{tabular}

\footnotetext{
${ }^{\mathrm{a}}$ Indonesian Rupiahs (IDR) per United States Dollar (USD).
} 
Education: According to Hanushek and Wobmann (2007) a 5\% of GDP increase is expected in 20 years when an education reform is introduced. In our study, the 5\% increase in GDP was converted to benefits per ha, and was progressively introduced into the model by $0.25 \%$ increase intervals up to year 20 , when $5 \%$ of GDP was reached, and flat from year 20-25.

\subsubsection{Economic appraisal of forest ecosystem services}

Economic services provided by the forest were categorised into provisioning services, social services and environmental services, regulating and supporting services. Each category was broken down into different items that were separately assessed either by calculation from own data gathered during the site visit (surveys and interviews) or by assuming data in relevant literature, as shown in Table 2. Monetary values obtained from surveys were converted to end of 2016 World Bank GDP per capita PPP (Purchasing Power Parity) by means of a conversion factor, which was calculated by dividing the value of this PPP (The World Bank, 2015) by the GDP in Jayapura (Knoema, 2010). Calculations made from survey results are detailed next.

Provisioning Services were calculated based on the replies from the survey. Local people were requested to give a monetary value (IDR currency) to the services they obtained from the forest. A range of values to choose from, were included in the survey. An average value of provisioning services was calculated and the total value was broken down into wood, medicine, food and fiber based on the importance rating of each of these provisioning services to the local population. Medicinal Value of the forest was considered important not only as a provisioning service for locals but also as a resource for genetic material provision, that could be utilized both by the traditional and the conventional medicine industries; the value of the industry was multiplied by the royalties (assumed 12.5\%) (data from Hanafi et al. (2013) and Pearce and Moran (1994)) and divided by the forest area in Indonesia to get to a per ha value. The value of the water provisioning services was obtained by calculating the area of the different ecosystems (rivers/waterflows, inland and coastal wetlands and tropical forest) present in the plantation concession and multiplying these areas by the provisioning service values given by de Groot et al. (2012).

Likewise, participants were asked to give a monetary value to the non-tangible wellbeing services obtained from the forest -such as fishing, hunting, knowledge, spiritual wellbeing and others- and an average value was calculated. The value of the tourism was calculated separately from the rest of wellbeing services, based on the tourism in Jayapura region. The number of tourists and their daily expenditures were estimated from the flights arriving per day; values were expressed on a per ha basis by dividing by the total area of Jayapura. If forests were lost, tourism would be diminished. The share of the plantation was calculated based on its area.

Concerning the environmental, regulating and supporting ecosystem services, the value of the climate change prevention was calculated from the amount of carbon stored by the forest and the soil above the carbon stored by the oil palm plantation (European Commission, 2010). The value of one ton of $\mathrm{CO}_{2}$ eq was assumed to be 30.4 USD t $^{-1}$, from Luckow et al. (2016), based on the value for the next 25 years. Fire protection services by the forest were calculated as the difference between the probability of having fire

Table 2

Working data and supporting information on the values assumed for the economic assessment of the ecosystem services.

\begin{tabular}{|c|c|c|}
\hline Working data for the economic model & Value & Supporting information \\
\hline \multicolumn{3}{|l|}{ Tangible provisioning services } \\
\hline Wood & $\begin{array}{l}\text { Own calculation (Results } \\
\text { section) }\end{array}$ & Data from survey at PT RML site \\
\hline Food (all products for eating, fish, meat) & $"$ & Data from survey at PT RML site \\
\hline Fiber & $"$ & Data from survey at PT RML site \\
\hline Local medicinal resources & $"$ & Data from survey at PT RML site \\
\hline $\begin{array}{l}\text { Global biochemical and pharmaceuticals (provision of genetic } \\
\text { material) }\end{array}$ & $"$ & $\begin{array}{l}\text { Calculation uses data from Hanafi et al. (2013); Pearce and Moran } \\
\text { (1994) }\end{array}$ \\
\hline Fresh water, groundwater recharge & $\begin{array}{l}\text { Own calculation (Results } \\
\text { section) }\end{array}$ & Calculation based on data by de Groot et al. (2012) \\
\hline \multicolumn{3}{|l|}{ Social services } \\
\hline Ecotourism and recreation & $\begin{array}{l}\text { Own calculation (Results } \\
\text { section) }\end{array}$ & Data from survey at PT RML site \\
\hline Aesthetic; value of the beauty & $\begin{array}{l}\text { Own calculation (Results } \\
\text { section) }\end{array}$ & Data from survey at PT RML site \\
\hline \multicolumn{3}{|l|}{ Environmental, Regulating and Supporting services } \\
\hline Climate change prevention & $\begin{array}{l}\text { Own calculation (Results } \\
\text { section) }\end{array}$ & European Commission (2010), Luckow et al. (2016) \\
\hline Air purification, air quality, air quality regulation & 12.00 USD ha $\mathrm{y}^{-1}$ & de Groot et al. (2012) \\
\hline Waste management/treatment & 8.20 USD ha $\mathrm{H}^{-1} \mathrm{y}^{-1}$ & Moratilla (2010) \\
\hline Reduction of Tsunami risk & $\begin{array}{l}\text { Own calculation (Results } \\
\text { section) }\end{array}$ & Calculation based on data from UNISDR (2015) \\
\hline Protection against fire & $\begin{array}{l}\text { Own calculation (Results } \\
\text { section) }\end{array}$ & Calculation based on data from Glauber and Gunawan (2016) \\
\hline Water cycle (supporting service) & $\begin{array}{l}\text { Own calculation (Results } \\
\text { section) }\end{array}$ & Calculation based on data by de Groot et al. (2012) \\
\hline Pollination services & 47 USD ha ${ }^{-1} \mathrm{y}^{-1}$ & Olschewski et al. (2006) \\
\hline Flora and fauna conservation & 22.56 USD ha $^{-1} \mathrm{y}^{-1}$ & Moratilla (2010) \\
\hline Soil formation/soil fertility regulation & $\begin{array}{l}\text { Own calculation (Results } \\
\text { section) }\end{array}$ & European Commission (2010) \\
\hline Nutrient cycle (supporting service) & 3 USD ha $^{-1} \mathrm{y}^{-1}$ & de Groot et al. (2012) \\
\hline Biological control & $11 \mathrm{USD} \mathrm{ha}^{-1} \mathrm{y}^{-1}$ & de Groot et al. (2012) \\
\hline Habitat service & 16 USD ha $^{-1} \mathrm{y}^{-1}$ & de Groot et al. (2012) \\
\hline Existence value & 43 USD ha $^{-1} \mathrm{y}^{-1}$ & TEEB (2009) \\
\hline Maintenance of genetic diversity & 46 USD ha $^{-1} \mathrm{y}^{-1}$ & de Groot et al. (2012) \\
\hline
\end{tabular}


on tropical forest and the probability of having fire in oil palm plantations (Beukering et al., 2003), multiplied by the potential cost of having fire. The cost of fire was calculated based on The World Bank (2016) for the oil palm land area, assuming the value of land planted with oil palm in Indonesia by Price Waterhouse Coopers (2010). The PT RML plantation was about $6 \mathrm{~km}$ from the sea; as the forest close to the sea acts as a protection barrier, this service was valued. It was estimated assuming 50-year return period for Tsunami and 50\% decrease in GDP per capita as Tsunami damage cost to the people living at the plantation (UNISDR, 2015). Soil formation/soil fertility regulation services were calculated from the value of emissions lost from the storage of carbon in the forest soil that were lost when transformed to oil palm, based on the methodology by European Commission (2010). In regard to the maintenance of genetic diversity, roughly half of the species in New Guinea were assumed to be native (IUCN, 2008), and therefore the average value estimated by de Groot et al. (2012) for the tropical forest biome was doubled to account for native and non native species. Water regulating services were assessed by calculating the areas of the different ecosystems (inland wetlands and tropical forest) present in the plantation concession and multiplying them by the regulating service values given by de Groot et al. (2012).

\subsubsection{Methodology for cost benefit analysis}

The cost benefit analysis aimed to determine if the establishment of oil palm plantations on forest land was feasible or not, in monetary, environmental and social terms. Feasibility was assessed by comparing the benefits/costs of the development scenario (oil palm plantation) to those of the conservation scenario (forest preservation). Results from the preservation scenario were substracted from those of the development scenario. Results from both scenarios were projected for a 25 year period. Revenues and costs were projected by using expected growth rates, and discounted with specific discount rates (see Table 1) appropriate for each model. The results were first substracted without applying a discount, later the discounted results were substracted to see which scenario was more benefitial, based on the economic benefits it provided in USD ha ${ }^{-1}$ for a 25 years period. If the benefits-costs of the development scenario were higher than the benefits-costs of the sustainable use of the forest (forest preservation scenario), the plantation would be more benefitial than the forest and if they were negative the forest would be more benefitial.

\subsection{Methodology for sensitivity analysis}

A sensitivity analysis was conducted to study the effect of magnitude changes of important variables in the model, given the fact that any economic appraisal is subjected to certain uncertainty.

Firstly, all escalations ( $3 \%$ increase in revenue prices and costs of oil palm plantation, $1 \%$ increase in the value of the social benefits of the plantation, $1 \%$ increase in ecosystem services value) were removed; these values were changed to $0 \%$. Secondly, a sensitivity scenario was computed without escalations (as described above) and without discount rates. Discount rates of $10 \%$ for oil palm plantation profits, $5 \%$ for the social benefits and $5 \%$ for the value of ecosystem services were changed to $0 \%$. Thirdly, changes in commodity prices were analyzed. Commodity market price variations of \pm 10 for crude palm oil and kernel oil area were applied. Fourthly, the oil palm yield was modified within the 3.92-6.04 $\mathrm{tha}^{-1} \mathrm{y}^{-1}$ range for Crude Palm Oil and within the $0.74-1.24 \mathrm{tha}^{-1} \mathrm{y}^{-1}$ range for Kernel Oil, taken for plantations in Papua from the article by Andrianto et al. (2014). Finally, variations of \pm 10 were applied for provisioning and regulating water ecosystem services.

\subsection{Methodology for switching values of emissions}

A switching value of an input parameter is the value rendering a net present value equal to zero. The $\mathrm{CO}_{2 \text { eq }}$ emissions price required for project breakeven was found by iterating the price of $\mathrm{CO}_{2 \mathrm{eq}}$ emissions (switching value) so that benefits from the plantation are equal to the benefits of the changes of the change in ecosystem services from the land use change.

\subsection{Methodology for LUC emissions calculation}

Emissions from LUC from Indonesian forests to oil palm were calculated in order to assess the global impact of this concept. The area converted from forest to oil palm was taken from official sources (Minsitry of Environment, 2018). Emissions per ha for forest in organic and peat soil were calculated based on European Commission (2010) and Intergovernmental Panel on Climate Change (2013). The value found for the Indonesian LUC emissions was divided by the value of the Indonesian total emissions as well as by value of the world global emissions, based on the data from CAIT (2018), in order to calculate the share of the Indonesian LUC emissions. Details of the assumptions made and information sources used for LUC emissions calculation are shown in Table 3.

\section{Results}

\subsection{Site visit and survey results}

\subsubsection{Plantation data}

Relevant information gathered during the site visit is given next. This information was obtained from interviews conducted to local professionals of the palm oil industry, such as company staff as well as company management, and from the site visits conducted. This qualitative description allows a better understanding of ground and regional conditions, supporting the economic analysis in this study.

3.1.1.1. Company. According to PT Rimba Matoa Lestari staff, the company was owned by a Chinese-Indonesian holding based in Jakarta. They did not have a roundtable on Sustainable Palm Oil (RSPO) certification, but they were planning to request it.

3.1.1.2. Plantation data. The feasibility studies started in 1999 , clearing began in 2005 and the start of plantation operations in 2010. According to company staff the plantation started in 2011, and only 5,000 ha were developed at the end of 2016. Due to the financial crisis the investment was slow and that was the reason that the commercial production of the plantation had not begun. In Fig. 1, a sequence of Google Earth historical images showing the transformation of the first 6,000 ha from forest to oil palm is given.

3.1.1.3. Location. Main reasons mentioned by the Company to choose Jayapura were: available land, suitable weather, and low population density. A river for irrigation was present upstream. Infrastructures were expected to be improved in the following years. The cost of land was low, only 2 million IDR per ha (149.25 USD ha ${ }^{-1}$ ). Also, the license to start the plantation could be finished in 2 years.

3.1.1.4. Permits. This area was considered by the Forestry Ministry as convertible land as the soil was organic without the presence of peat. Apparently local permits were issued without too many problems. The permits were issued in two years: 2008 to 2009. Environmental Impact Assessment study was recommended locally. There was village, regional (Jayapura Government), provincial (Papua) and final approval from the Indonesian central government. 
Table 3

Working data and supporting information for the calculation of Indonesian emissions from LUC from forest to oil palm plantation.

\begin{tabular}{|c|c|c|}
\hline Working data & Value & Supporting information \\
\hline Area of Undisturbed Mineral forest converted to oil palm (Mha) & 140.10 & Ministry of Environment and Forestry Republic of Indonesia (2018) \\
\hline Area of Undisturbed Peat forest converted to oil palm (Mha) & 102.75 & Ministry of Environment and Forestry Republic of Indonesia (2018) \\
\hline 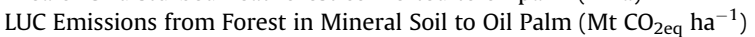 & 623.30 & Own calculation based on European Commission (2010) \\
\hline LUC Emissions from Forest in Peat Soil to Oil Palm $\left(\mathrm{Mt} \mathrm{CO}_{2 \mathrm{eq}} \mathrm{ha}^{-1}\right)$ & 832.80 & Own calculation based on Intergovernmental Panel on Climate Change (2013) \\
\hline LUC emissions from forest to oil palm $\left(\mathrm{Mt} \mathrm{CO}_{2 \mathrm{eq}}\right)$ & 172.90 & Own calculation based on above data \\
\hline Indonesian LUC Emissions ( $\mathrm{Mt} \mathrm{CO}_{2 \mathrm{eq}}$ ) & $1,682.16$ & CAIT (2018) \\
\hline Indonesian Total Emissions ( $\mathrm{Mt} \mathrm{CO}_{2 \mathrm{eq}}$ ) & $2,471.64$ & CAIT (2018) \\
\hline World Total Emissions ( $\mathrm{Mt} \mathrm{CO}_{2 \mathrm{eq}}$ ) & $48,892.00$ & CAIT (2018) \\
\hline
\end{tabular}
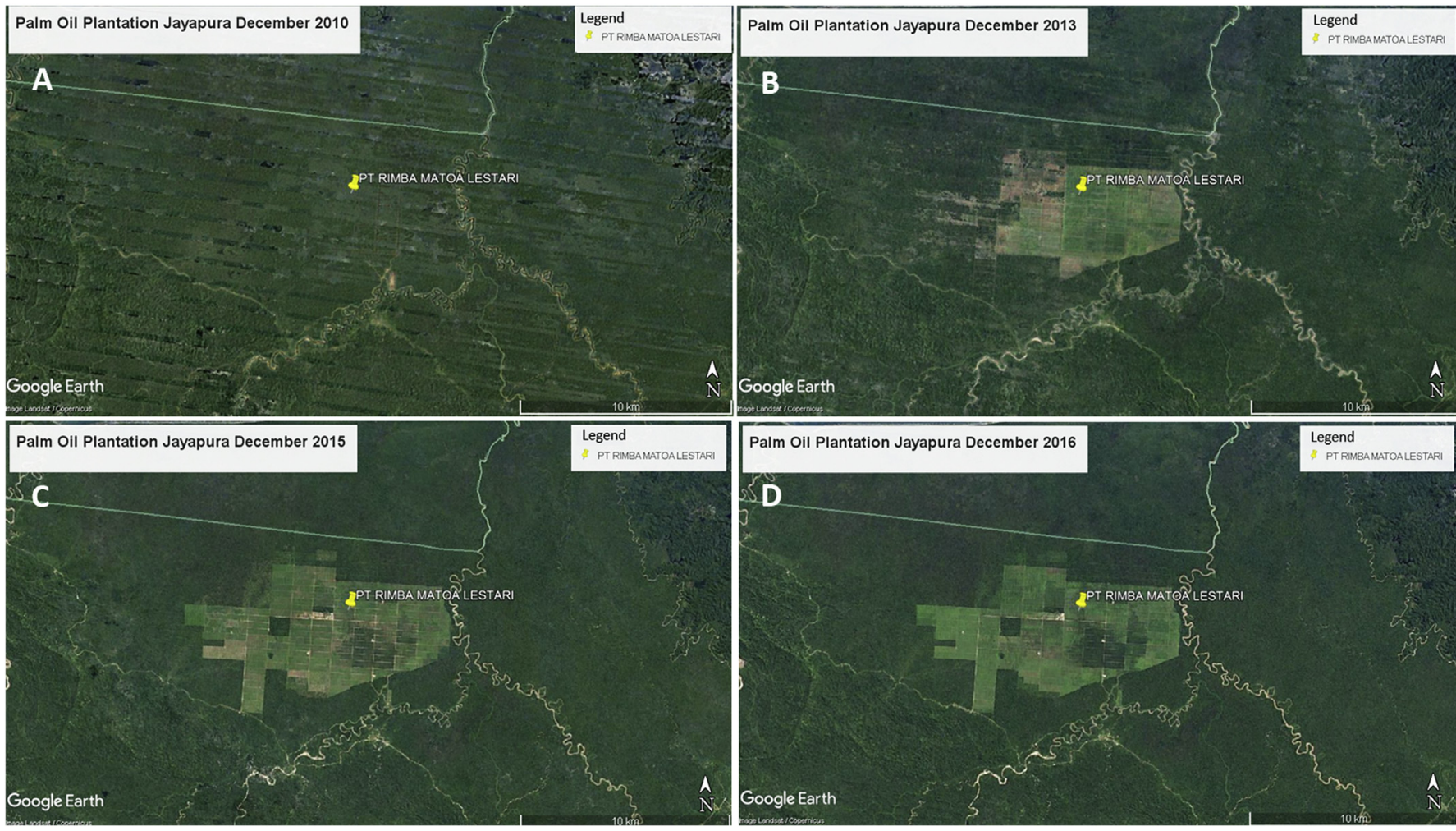

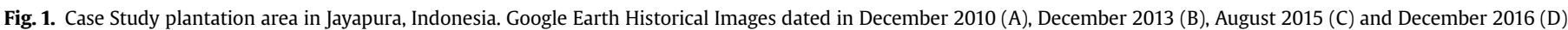

\subsubsection{Agricultural practices}

- Plantation density: $10 \times 6 \mathrm{~m}$ configuration.

- Nursery: Nursery with different sectors and levels of development by year.

- Weeding: Not very good in some areas, planting of low vegetation was conducted to avoid erosion.

- Time for first harvesting: After 4 years, fruits were not ready for harvesting, probably after $1-2$ more years harvest would start. A 6-7 years period was expected to get production.

- Yield till not certain but prediction was good.

- Machinery utilized: For clearing big equipment with cutting and shear capabilities was utilized. Weeding was manual by saw. For planned harvesting, manual saw and chisel; all manual cutting.
- Types of fertilizers: N P K(B) 12-12-8 (2)

- Origin of fertilizers: China.

- Type of soil: Sandy organic, organic soil in the first layer, followed by alluvial organic soil in layers below. The Ministry of Forestry assigned the permits based on soil type.

- Mulching: Vegetation was planted between palm trees to avoid erosion; no erosion was occurring.

- Irrigation: By water channels; there was a system of gates to control water level and inundate the different plots.

- Drainage systems: channels network.

- Water: Sufficient year-round due to the presence of a river at the plantation. 
- Needed labor, skilled and unskilled: 50 skilled workers (permanent employees) and 700 workers (temporary with yearly renewable contracts) were working on the 5,000 ha of plantation already established. Employees had to complete weeding for about 0.5 ha per day to receive their full salary. There were about 0.12 workers per ha, to be increased up to a normal $0.3-0.64$ workers per ha range after start of harvesting and CPO (Crude Palm Oil) production.

- Plantation Management: construction of channels for irrigation, erosion control by mulching planting, and experienced management and labor are believed to guarantee a correct management of the plantation. Workers were requested a minimum output to get the full salary guaranteeing that the weeding operations were conducted. Possibly a higher investment in machinery could improve the efficiency of the operations, that were relying mainly on labor.

3.1.1.6. Economics. Elkington's triple bottom line logic (Elkington, 1997) is followed in order to present qualitative information on Economics that were gathered during the site visits.

3.1.1.7. Economic value. The main motivation for the Company was to obtain economic income from the plantation. Some of the factors affecting profitability that were highlighted during the site visits are the followings:

- Transportation: The cost to transport the palm oil from Jayapura was expected to be high due to the lack of proper infrastructures. A bad condition national asphalted road connected the plantation with Jayapura.

- Refining: The Company was building a crude palm oil (CPO) processing facility that would only process the palm fruit up to CPO level. No methane recovery or palm oil mill effluent (POME) treatment facilities had been planned.

- Oil price: CPO Price was expected to be set by international markets; no certification was available (as of December 2016) so probably in the first stages the CPO could not be sold at the highest price. It was stated that it was not possible to sell to Europe or USA, so probably it would be sold within Asia.

3.1.1.8. Environmental impact. The new plantation entailed very important environmental consequences due to the transformation from forest to oil palm. Information on the Company environmental practices are reflected in this section.

- Establishment: The expected establishment costs were 50 million IDR per ha until production started. This cost included the clearing of the forest, construction of irrigation channels, construction of roads, camps, provision of electricity, fertilizers, nursery and planting, as well as the cost of labor for agricultural operations such as weeding. There was no cost of pesticides as manual weeding was conducted. Clearing of the forest, which represents the main environmental consequence of the plantation, was done mechanically. This is a much more sustainable practice than burning.

- Wood: Revenues from wood selling when clearing the forest were obtained; $1 \mathrm{~m}^{3}$ of good quality wood was 5.8 million IDR (Indonesian Rupias). The company sold the wood and paid a small fee, so a good profit was made. The wood was sold raw in the local market. The Company did not clear additional forest previous to planting in order to obtain additional profits from wood selling, which is a common non-sustainable practice, not present in this plantation.

- Renewable Energy: It was not clear if the CPO from the oil palm plantation would be used for biodiesel. The company did not have a certification so it would be complicated to sell it for this purpose. According to the new regulation from the EU (European Parliament, 2018), palm oil will not be used as a biofuel after 2020, therefore in Europe the CPO will not be sold to be used as biofuel.

3.1.1.9. Social responsibility. This is a very important issue when establishing new plantation; respecting the rights of customary communities as well as workers and the local population is of critical importance.

- Land Use Change: The land was leased for 35 years. There were about 15 land owners; each of them received an initial 80 million IDR payment. The land before the change to oil palm plantation was primary forest. A socialization process was conducted among the landlords. Once an agreement was reached with the landlords the project passed to the local government for approval. No conflicts occurred when purchasing the land, due to Company socialization and discussion with landlords and local leaders. The company had to fulfill the plasma scheme commitment, in order to avoid riots and problems with local community and workers. Low population density allowed for an easier process. The plantation had no fence, only an open gate; people were permitted to pass freely.

- Labor: The Company had legal contracts with employees; conditions were competitive according to Indonesian standards. The cost of labor was 2.5 million IDR per worker (104,000 per day by average 24 days, Monday to Saturday work). One worker had to take care of the weeding of 8 ha per month, so the cost of weeding was about 312,000 IDR ha $^{-1}$ month $^{-1}$. The number of workers in the oil palm plantation was reduced from 1,000 to 700 (as of December 2016) due to economic issues. Labor reduction had made the implementation process slower as weeding operations had been reduced and plantation of additional area had been slowed down. Most workers were transmigrants from other Indonesian regions. Drivers and security guards were local workers. Some locals said they had been rejected due to lack of qualifications. In this sense the plantation would have to make a greater effort to engage local workers, by conducting oil harvesting training programs.

- Access to the clinic for the community had been provided. No education had been provided yet but a school bus had been provided by the Company to take worker's kids to the local school outside the plantation. Some new local businesses, that sold supplies to the plantation and their workers, had been established. This benefit was part of the social responsibility of the Company.

- Plasma Scheme: There was a planned plasma scheme, which meant that land would be given to local farmers to develop their own plantations, selling later the production to the Company. Financial support from the Company would be obtained. There was a plan for 700 families that would get 4 ha each; a total of 2,800 ha ( $10 \%$ of the total land) would be given to the local community for plasma plantation. The families would pay 50,000 IDR per month until reaching 1,050,000 IDR to get their certificate of lease for 35 years. According to the Company $20 \%$ of total plantation area was committed for plasma, so up to 5,600 ha could be given to the local population. The company had made an effort to integrate the community into the plantation. 
- Industries: There were no downstream industries in the area. Upstream local industries benefited from the plantation by the purchase of construction materials. For food and other basic supplies, few products were available; plantation supplies were primarily imported or came from Jakarta.

- Infrastructures inside the plantation: These infrastructures were developed by the plantation Company to give service to the plantation; they were developed prior to the start of the plantation operations. Common infrastructures were developed only inside the plantation such as roads, houses, mosque, church, workers housing complex, office building and clinic to give service to plantation workers, in addition to irrigation channels required for oil palm irrigation. Social facilities included religious buildings, houses, wells for drinking water supply and electricity by diesel generators. Water supply was only for consumption inside the plantation; it was supplied by wells for plantation workers use. Electricity supply by diesel generators was only for consumption inside the plantation. The company shares these infrastructures with the local population, becoming a social benefit for them.

- Infrastructures outside the plantation: The Ministry of Public Works (PU) was present in the region and bridges were constructed along the road to Jayapura; this road was being improved. This was part of the Government's plan to develop the region, regardless of the plantation. The road going to Jayapura is of critical importance in order to allow palm oil transportation to Jayapura's port. The new infrastructures promote regional growth and reduce isolation.

3.1.1.10. Plantation future strategy. Plans for future expansion were up to the licensed 28,000 ha. The plantation would be producing in a few years; in about 5 years the whole licensed area was expected to be planted and $\mathrm{CPO}$ production was expected to start in a few years.

Associated upstream and downstream industries were expected to develop as the plantation went into production.

\subsubsection{Survey results}

Concerning the oil palm establishment, respondents stated that there had been a new plantation established in the past years; in 1999 surveys were conducted, and in 2005 equipment was mobilized.

All the respondents stated the plantation was established in forest land. The clearing seemed to be of about 5,000 ha and was being conducted gradually.

About half of the respondents (58\%) stated that the establishment of the plantation was smooth (Fig. 2). At the beginning there were tensions that were resolved during the negotiations between the Company and the local leaders and landlords, based on the promise to give plasma to 700 families, with an area of 4 ha per family. As the production had not started yet, final acceptance by the population was pending. Respondents stated they would accept the plantation if they were given a share through the plasma scheme. Most respondents (79\%) believed that compensation had been paid to land owners; $75 \%$ of the respondents were of the opinion that land had been allocated to local communities but only $42 \%$ of the respondents believed that the required $20 \%$ had been allocated.

Respondents were asked their opinion of oil palm plantations; $46 \%$ of respondents had a good or very good perception, $33 \%$ a neutral perception and $13 \%$ a bad or very bad perception (Fig. 3). Those having a bad perception were generally locals with Papua origins, people that make a living from the forest and after its removal had lost this asset. The plantation could bring economic benefits for those that were willing to engage in its activities, but the loss of the forest could not be replaced.

In contrast, positive perception came from plantation workers; many of them trusted they would be given some land to become an oil palm plasma entrepreneur. Plasma entrepreneurs are locals given a small land area ( 4 ha at this plantation) by the Company to start up their own oil palm plantation business. They are given financial support by the Company, which buys their production at an agreed price.

The low population in the region would allow the plantation owners to give land to most of the local people. This would create a good relationship with the local indigenous population. Small holders and plantation workers were the primary types of relationships the local population had with the plantation.

Participants were requested to highlight the benefits they obtained from the plantation including education, healthcare, access to jobs and a more open society. They were also requested to address the negative effects of the plantation: Deforestation, followed by the decrease in wood and in other forest products, was perceived by the local population as the most important negative effect from the plantation (Fig. 4).

Next questions in the survey tried to determine if local population depended on the forest to make a living and the importance of the forest for them. It was found that $83 \%$ respondents depended on the forest, and $71 \%$ rated its importance as very high (Fig. 5).

In order to evaluate the value of provisioning ecosystem services, respondents were asked which tangible services they obtained from the forest, as well as the level of income derived from these services. Wood and food were identified as the most important tangible services, while hunting and fishing were identified as the most important non-tangible ones (Fig. 6). The value of provisioning services was more easily perceived than the one of nontangible services (Fig. 7). A positive relationship was observed between the income level of participants and the level of tangible (provisioning) and non-tangible ecosystem services. Interestingly, the oil palm plantation workers gave high value to benefits obtained from the forest.

Lastly local villagers were asked to recommend potential improvements for the plantation. Access to education (50\%), profit sharing (50\%) and access to health (46\%) were the main recommendations given by the local population to the oil palm company (Fig. 8).

\subsection{Economic model results}

\subsubsection{Plantation economic results}

In Table 4 the financial results of the economic model for the oil plantation are summarized. The average yearly earnings amounted to $3,924.56$ USD $^{-1} \mathrm{ha}^{-1}$. Plantation earnings over time are depicted in Fig. 9; earnings are negative the first three years, breakeven is reached in year 6 , increase steadily from year 6 to year 12, then start descending progresively until the end of the cycle.

The distribution of taxes into the national, regional and district categories is shown in Table 5 . About $80 \%$ of the taxes are paid at the national level; this fact would explain the apparent interest of the central government to allow the development of oil palm plantations in forested areas. Benefitial aspects have to be compared with the benefits that the forest gives to society and see which benefits are higher.

\subsubsection{Social benefits brought by the plantation}

The improved life expectancy resulted in 54.61 USD ha $^{-1} \mathrm{y}^{-1}$ social benefit in terms of health. This value was introduced into the model from year one as the clinic had been made available by the Company from the beginning. Likewise, the value of the investment 


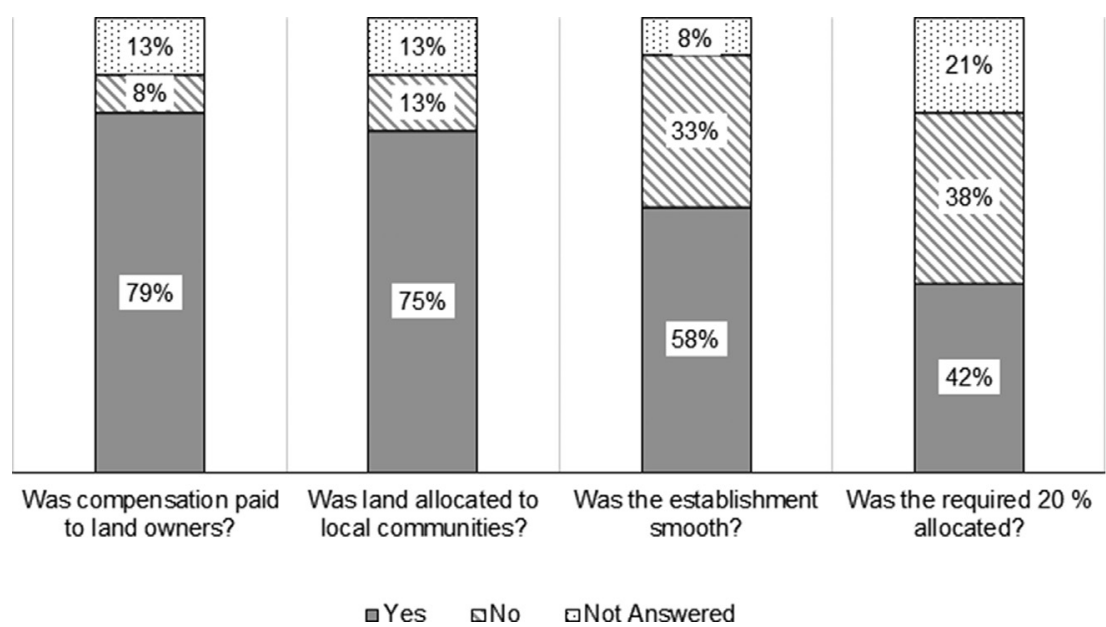

Fig. 2. Survey results regarding the plantation establishment.

\section{Perception of plantation by local people}

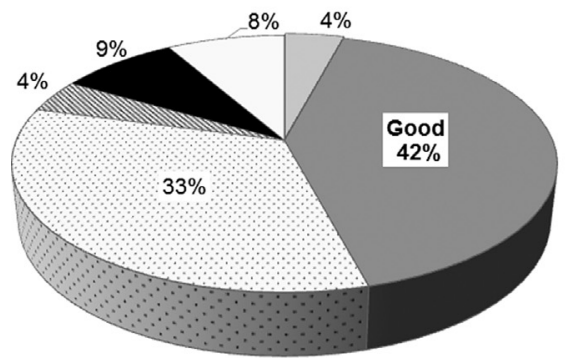

\section{Local population relationship with the plantation}

口Very Good
口Good
口Average
\& Bad
$\square$ Very Bad
$\square$ Not answered

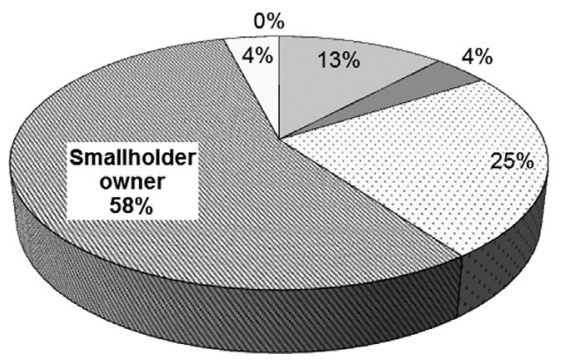

None

口Suffer negative effects

口Benefit from positive effects

aWork at

plantation

هSmallholder owner

口Not answered

Fig. 3. Perception and relationship of the local population with the plantation.

Benefits of the plantation

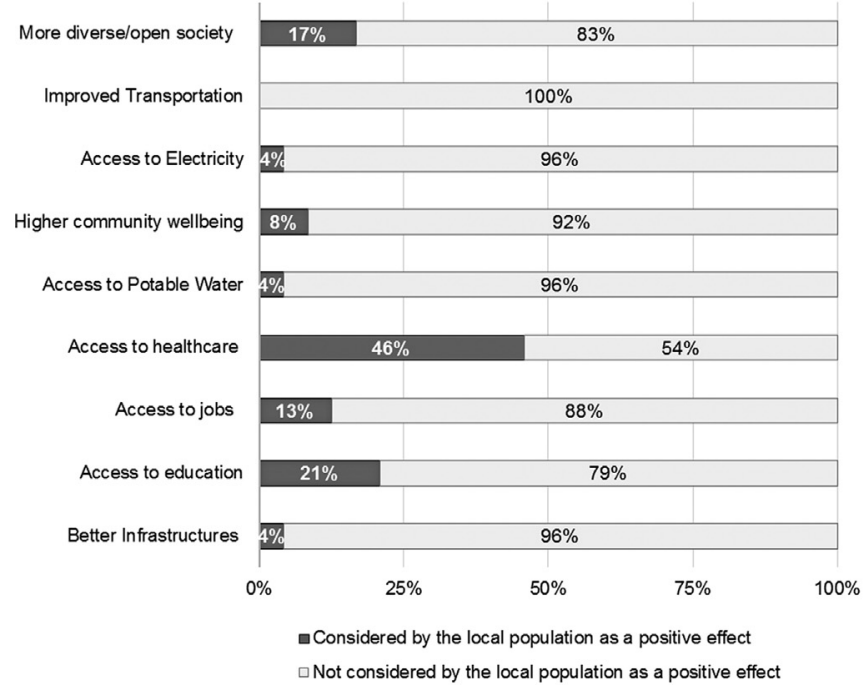

Negative effects of the plantation

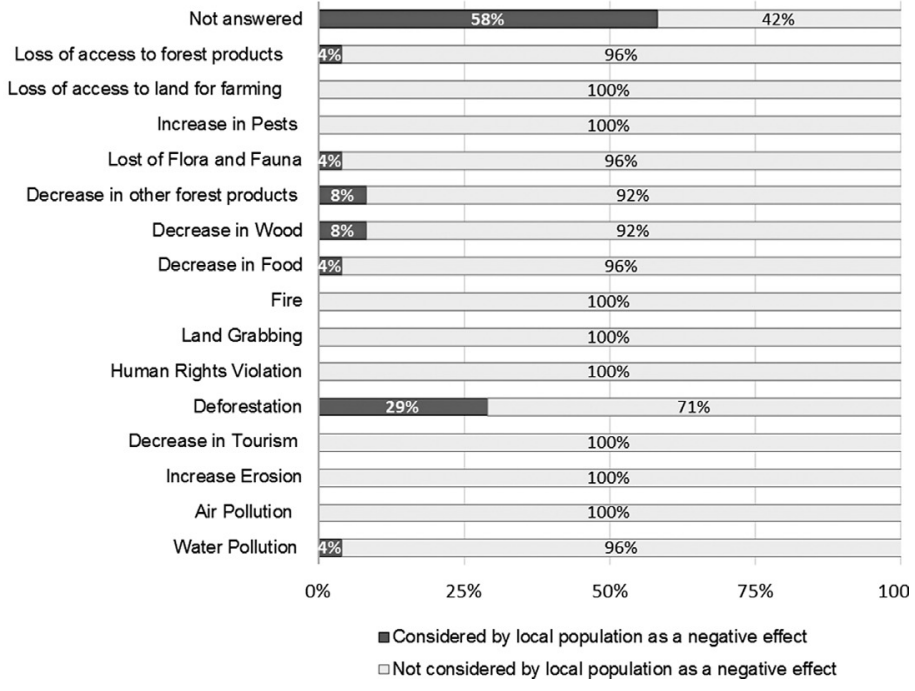

Fig. 4. Positive and negative effects of the plantation to the local population.

in infrastructures, amounting 447.00 USD ha ${ }^{-1}$, was introduced into the model as a benefit to the local population. It was distributed in the first 5 years of the project. The education plans had the potential to increase GDP by $5 \%$ in a period of 20 years. The value of $0.25 \%$ of GDP of the local population was equal to $3.41 \mathrm{USD} \mathrm{ha}^{-1} \mathrm{y}^{-1}$.
This value was progressively increased to a maximum of 68.26 USD $\mathrm{ha}^{-1} \mathrm{y}^{-1}$ for the period between year 20 and year 25 .

\subsubsection{Economic appraisal of forest ecosystem services}

As explained in the Methods section, the value of eleven out of 

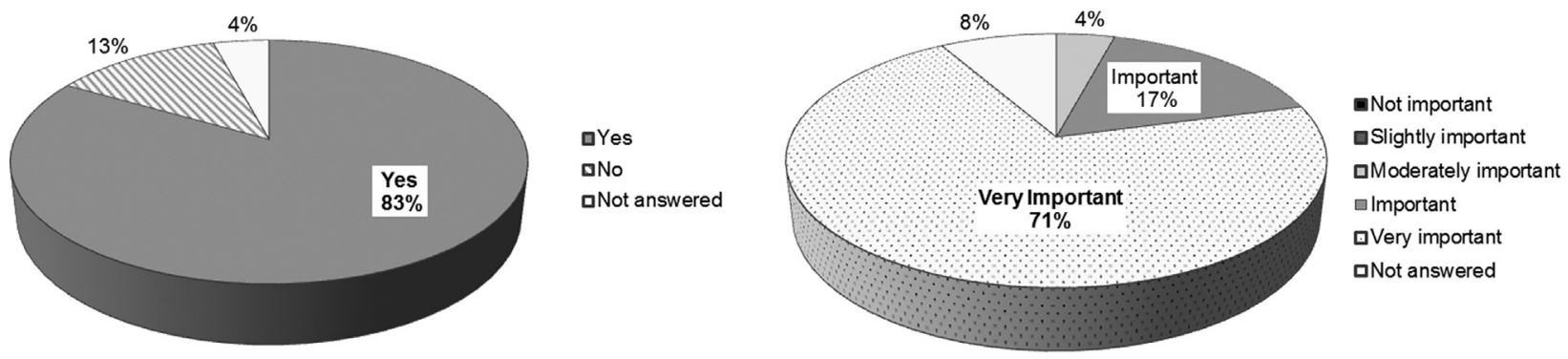

Fig. 5. Dependency and importance of forest for the local population.

Tangible forest services obtained from the forest

Importance of forest non-tangible services
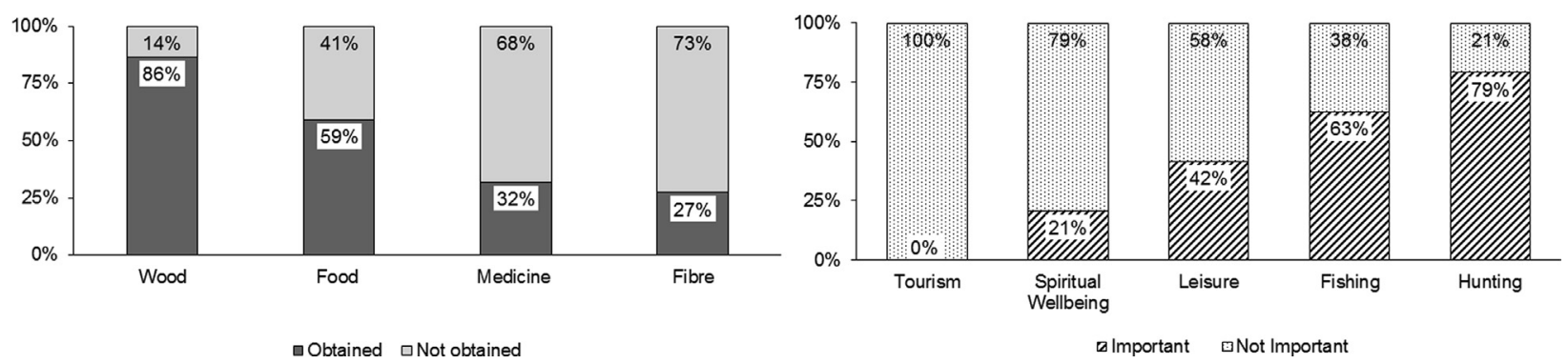

Fig. 6. Tangible and Non-tangible ecosystem services obtained from the forest by the local population.

\section{Local people monthly income derived from the forest}

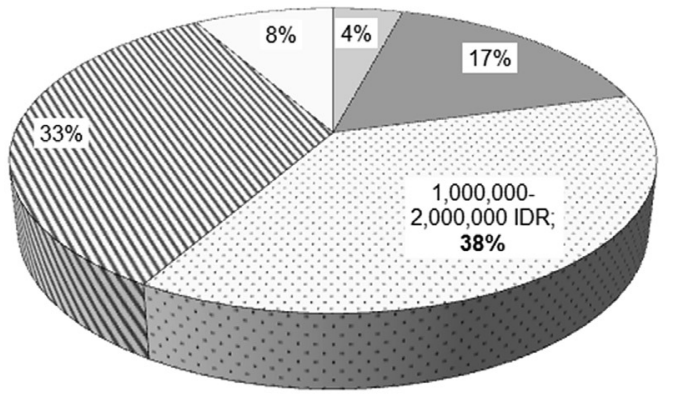

$\square<500,000$ IDR
$\square>2,000,000$ IDR

\section{Represented monthly value of wellbeing forest services}

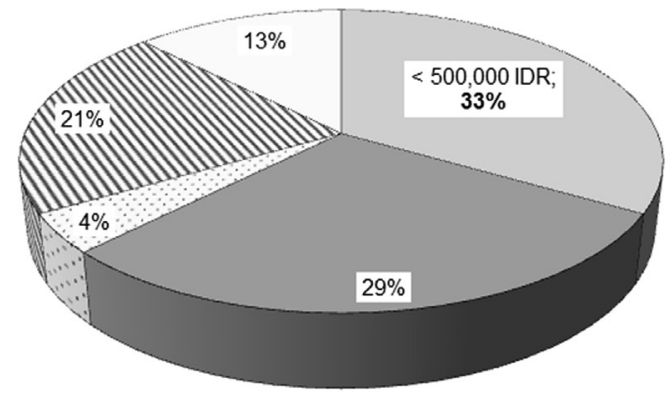

$\square 500,000-1,000,000$ IDR $\quad \square 1,000,000-2,000,000$ IDR 口Not answered

Fig. 7. Economic value derived by locals from tangible and non-tangible ecosystem services.

twenty-four ecosystem services were calculated from site visit data and/or survey results; the remaining ecosystem services were assessed assuming literature values (see Table 2). Results of own calculation services are commented next.

The value of the provisioning ecosystem services from the forest was estimated at 1,586.41 USD ha ${ }^{-1} \mathrm{y}^{-1}$ from calculations based on the mean value given by survey respondents to the provisioning services (36,000,000 IDR per person and year); tangible provisioning services represented two thirds of the total, based on survey data. The mean value was adjusted by the 2016 prevailing World Bank PPP $(12,849.79$ USD per person and year $)$ and this value was referred to area (ha) taking into account the area of Jayapura $(1,115,715 \mathrm{ha})$, the area of the plantation $(28,000 \mathrm{ha}$, according to survey) and the population living near the plantation (3,456 people). From this value and the importance given by the respondents to the different ecosystem services, the values of the wood, medicine, food and fibre provisioning services were estimated at 475.92, 105.76, 370.16 and 105.76 USD ha $^{-1} \mathrm{y}^{-1}$. Provision of genetic material, to be utilized both by the traditional and the conventional medicine industries was estimated at 112.60 USD ha $^{-1}$, following the approach described in section 2.2.2. Water provisioning ecosystem service from the forest was calculated from the value of the different ecosystems present in the area of the plantation, amounting to 100.73 USD ha $^{-1} \mathrm{y}^{-1}$.

With regard to social services, the forest provides aesthetic, leisure, spiritual and wellbeing both to the local population and to 


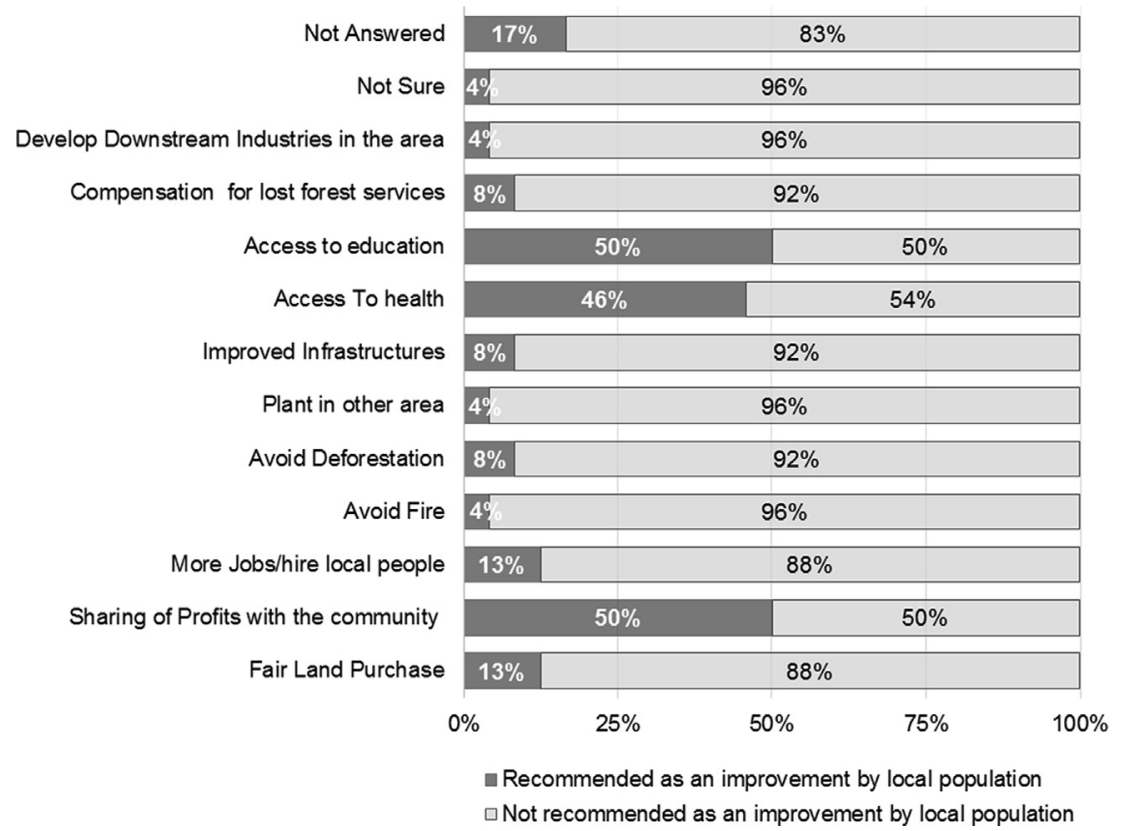

Fig. 8. Recommendations for improvement given to the oil palm company.

Table 4

Financial results of the oil palm plantation.

\begin{tabular}{ll}
\hline & Financial Results \\
\hline Return on Investment (ROI) & $174 \%$ \\
Internal Rate of Return (IRR) & $38.48 \%$ \\
Repayment period & 6 years \\
Earnings before tax & $98,113.94 \mathrm{USD} \mathrm{ha}^{-1}$ \\
Average yearly earnings & $3,924.56 \mathrm{USD} \mathrm{y}^{-1} \mathrm{ha}^{-1}$ \\
Discounted earnings 10\% & $22,754.00 \mathrm{USD} \mathrm{ha}^{-1}$ \\
\hline
\end{tabular}

the global population in the form of tourism; the plantation area is very beautiful with important touristic destinations such as Sentani Lake that is still nearly untouched. Site remoteness does not allow capturing the full potential value of the climax forest in this region. The value of non-tangible wellbeing services to the local population were estimated at 528.80 USD ha $^{-1} \mathrm{y}^{-1}$, based on survey data. These services represent the possibility to hunt and fish, views for resting and a place to go with the family; also the place for knowledge. The second non-tangible ecosystem service is tourism. Sentani Lake, which is the most notorious touristic destination of this area is about $50 \mathrm{~km}$ distance from the plantation. Following the methodology described in section 2.2.2, a value of 70.66 USD ha ${ }^{-1}$ $\mathrm{y}^{-1}$ was reached for the tourism ecosystem service.

Within the environmental, regulating and supporting services, four services (climate change prevention, reduction of Tsunami risk, protection against fire and water cycle) were assessed by own calculation. The value of the climate change prevention service was assumed to be equal to the value of the Land Use Change (LUC); it was calculated as the product of $\mathrm{CO}_{2}$ eq emissions due to LUC (623.3t CO eq (2) ha $\mathrm{ha}^{-1} \mathrm{y}^{-1}$, following the methodology of the European Commission (2010), and the value assumed for $\mathrm{CO}_{2}$ eq (30.4 USD t ${ }^{-1}$, based on the mid case price forecast by Luckow et al. (2016). Possible damage caused by fire related to oil palm was estimated at $6,211,038,219 \mathrm{USD} \mathrm{y}^{-1}$ or $887.29 \mathrm{USD}^{-1}$ haring El Niño phenomenon years, from fire statistics by Glauber and Gunawan (2016), (16,000,000,000 USD total fire damage cost in

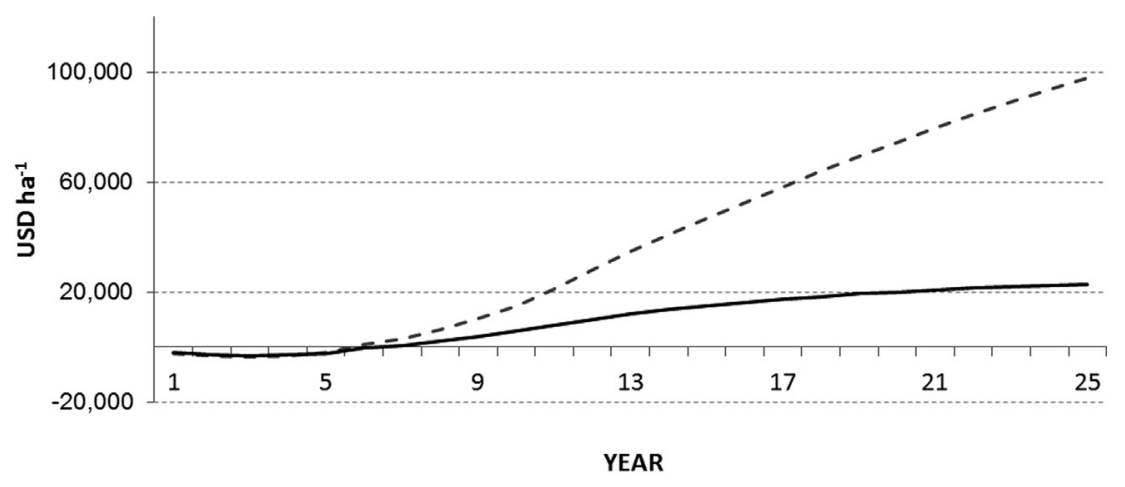

- Accumulated Commercial Plantation Earnings
- Discounted (10\%) Accumulated Commercial Plantation Earnings

Fig. 9. Plantation earnings. 
Table 5

Taxes distribution.

\begin{tabular}{|c|c|c|c|}
\hline Taxes Distribution for a 25-year period & National & Region & District \\
\hline Property tax, taxable sale value of the company land - $50 \%$ of Land Value & $10.0 \%$ & $16.2 \%$ & $73.8 \%$ \\
\hline Personal Income Tax & $80 \%$ & $12 \%$ & $8 \%$ \\
\hline Corporate Tax & $80 \%$ & $12 \%$ & $8 \%$ \\
\hline Value added tax $-10 \%$ of Revenue & $100 \%$ & $0 \%$ & $0 \%$ \\
\hline Property tax, taxable sale value of the company land - $50 \%$ of Land Value (USD ha ${ }^{-1}$ ) & 457 & 740 & 3372 \\
\hline Personal Income Tax (USD ha ${ }^{-1}$ ) & 2,447 & 367 & 245 \\
\hline Corporate Tax (USD ha ${ }^{-1}$ ) & 26,818 & 4,023 & 2,682 \\
\hline \multirow[t]{2}{*}{ Value added tax $-10 \%$ of Revenue (USD ha ${ }^{-1}$ ) } & 15,362 & & \\
\hline & 45,083 & 5,130 & 6,298 \\
\hline
\end{tabular}

Indonesia and 39\% fired area possibly related to oil palm). The return period of fire occurrence was assumed to be reduced from a return period of 5 years in case of oil palm plantation to a return period of 50 years if the natural tropical forest was in place (Beukering et al., 2003). Therefore, the benefit from the forest was estimated at 159.7 USD ha ${ }^{-1} y^{-1}$. The ecosystem service of soil formation/soil fertility regulation was assessed as the value of loss of forest soil carbon storage based on (European Commission, 2010); additional fertility was not included in this calculation. The amount of $\mathrm{CO}_{2}$ eq avoided by retaining the organic matter in the soil ( $153.72 \mathrm{tha}^{-1}$ ) was multiplied by the value of $\mathrm{CO}_{2}$ eq and divided by the 25 year plantation period, reaching to a value of 184.5 USD ha ${ }^{-1} \mathrm{y}^{-1}$. The last calculated service was the one associated with Water, which was valued from the value of the different ecosystems present in the plantation, amounting to 586.40 USD $\mathrm{ha}^{-1} \mathrm{y}^{-1}$

From the abovementioned values, and the values taken from literature (Table 2), the total ecosystem benefits of climax tropical forest in Papua, above those of the oil palm plantation were valued at 3,795.44 USD ha ${ }^{-1} \mathrm{y}^{-1}$ (Table 6). If the benefits from oil palm are added back, the value of forest ecosystem services amounts to 4,449.13 USD ha ${ }^{-1}$. de Groot et al. (2012) estimated the value of the tropical forest at 5,264 USD ha $\mathrm{y}^{-1}$. The estimate by World Bank (2009) for the value of Papuan or West Papuan forest was 5,700 USD ha $\mathrm{h}^{-1} \mathrm{y}^{-1}$. These values are slightly higher than the ones obtained in this study, probably due to the remoteness of the site and the low GDP per capita in the region.

\subsection{Cost benefit analysis results}

After analyzing the benefit values of the commercial plantation and of the forest independently a discounted cash flow, cost benefit analysis, was run. The cash flow was discounted for each scenario (see Fig. 10).

The benefits from the plantation were substracted from those of the forest ecosystem services for a 25 year plantation cycle. Benefits for the plantation amounted to 101,381.39 USD ha ${ }^{-1}$ while the socioeconomical benefits of the Papua tropical forest were $108,229.42$ USD ha $^{-1}$ for a 25 year return period. From these values, the average non discounted value of benefits for the plantation was 4,055.26 USD ha ${ }^{-1} \mathrm{y}^{-1}$, while for the forest ecosystem services was 4,329.18 USD ha ${ }^{-1} \mathrm{y}^{-1}$.The difference between benefits, for a 25 year cycle, was $-6,848.03$ USD ha ${ }^{-1}$; therefore the benefits of the forest are higher than those of the plantation for a 25 year cycle. When subtracting discounted benefits a value of $-34,722.75$ USD $\mathrm{ha}^{-1}$ for 25 years was obtained (Table 7 ).

\subsubsection{Sensitivity analysis results}

A sensitivity analysis for the socio-economic model was run varying some of the critical variables. Firstly all the escalations (3\% increase in revenue prices and costs of oil palm plantation, $1 \%$ increase in ecosystem services value) were removed. In this scenario profits from the plantation fell to $53,824.40 \mathrm{USD} \mathrm{ha}^{-1}$ and the benefits from the forest to $94,886.05$ USD ha $^{-1}$. The difference was $-41,061.65$ USD ha ${ }^{-1}$. The second sensitivity scenario was computed without escalations and without discounting; this way the benefits from the forest were 3,795.44 USD ha ${ }^{-1} \mathrm{y}^{-1}$ and the profits from the plantation 2,153.00 USD ha $\mathrm{H}^{-1} \mathrm{y}^{-1}$.

Changes in commodity prices were analyzed. The commodity market prices for crude palm oil and kernel oil were varied $\pm 10 \%$. A $10 \%$ increase in palm oil prices resulted in $116,743.18$ USD ha $^{-1}$ plantation benefits over a 25 year cycle, a value very similar to the benefits of the forest ecosystem services in the basic scenario $\left(108,229.42\right.$ USD ha $\left.^{-1}\right)$. When the commodity palm oil prices were decreased by $10 \%$, the profits of the oil palm plantation dropped to $86,019.60$ USD ha $^{-1}$, a value much lower than the value of the forest ecosystem services. Therefore, the sensitivity analysis for the prices commodities showed that these variables can greatly change the results of the model.

The range of yields (3.92-6.04 tha $\mathrm{ha}^{-1} \mathrm{y}^{-1}$ for Crude Palm Oil and 0.74-1.24 $\mathrm{tha}^{-1} \mathrm{y}^{-1}$ for Kernel oil) expected for the plantation (Andrianto et al., 2014), resulted in a range of values for the plantation profits from $80,478.08$ to $151,257.17$ USD ha ${ }^{-1}$. These values highlighted that oil palm yields had a great impact on the results of the model.

Lastly, a variation in the value of the water ecosystem services benefits by $\pm 10 \%$ gave a value of the forest ecosystem services of 106,270.07-110,118.81 USD ha ${ }^{-1}$. Therefore the sensitivity analysis showed that the variation in the water ecosystem benefits did not have a great impact on the model results.

\subsubsection{Influence of $\mathrm{CO}_{2}$ eq emissions values}

The next analysis performed was to iterate the value of the $\mathrm{CO}_{2}$ eq emissions in order to determine at what value of emissions the value of the benefits of the plantation equaled that of the forest in the basic scenario. It was found that at 22.36 USD per ton of $\mathrm{CO}_{2}$ eq the model broke even and the plantation commercial benefits equaled the socioeconomical services of the climax tropical forest in our Papua Case study.

\subsubsection{Wealth redistribution. Winners and losers}

Wealth redistribution from LUC from forest to oil palm was analyzed; not only is important to understand if this project is feasible, but also who is benefitting or losing from this conversion process.

Forest ecosystem services and commercial plantation profits distribution without and with plasma scheme are shown in Fig. 11. These results reveal that the benefits from the forest ecosystem services are mainly shared by the local population in the form of provisioning and regulatory services and by the global population in the form of carbon storage and $\mathrm{CO}_{2}$ eq avoided emissions. After the transformation from forest to oil palm the profits change hands, 
Table 6

Socioeconomic matrix of the ecosystem benefits of Jayapura climax forest in mineral soil.

\begin{tabular}{|c|c|}
\hline Ecosystem services & Benefit (USD ha ${ }^{-1} \mathrm{y}^{-1}$ ) \\
\hline \multicolumn{2}{|l|}{ Economic provisioning benefits/cost } \\
\hline Wood & 475.92 \\
\hline Food & 370.16 \\
\hline Fiber & 105.76 \\
\hline Local medicinal resources & 105.76 \\
\hline Global biochemical and pharmaceuticals & 112.60 \\
\hline Fresh water, groundwater recharge & 100.73 \\
\hline Total provisioning services & $1,270.94$ \\
\hline \multicolumn{2}{|l|}{ Social benefits/costs } \\
\hline Ecotourism and recreation & 70.66 \\
\hline Wellbeing/Aesthetic & 528.80 \\
\hline Total social services & 599.46 \\
\hline \multicolumn{2}{|l|}{ Environmental, regulating and supporting benefits/costs } \\
\hline Climate change prevention & 758.40 \\
\hline Air purification, air quality, air quality regulation & 12.00 \\
\hline Waste management/treatment & 8.20 \\
\hline Reduction of Tsunami risk & 27.30 \\
\hline Protection against fire & 159.70 \\
\hline Water cycle & 586.40 \\
\hline Pollination services & 47.00 \\
\hline Flora and fauna conservation & 22.56 \\
\hline Soil formation/soil fertility regulation & 184.50 \\
\hline Nutrient cycle & 3.00 \\
\hline Biological control & 11.00 \\
\hline Habitat service & 16.00 \\
\hline Existence value & 43.00 \\
\hline Maintenance of genetic diversity & 46.00 \\
\hline Total Environmental, regulating and supporting services & $1,925.03$ \\
\hline Total value of the ecosystem services & $3,795.44$ \\
\hline
\end{tabular}

passing mainly to the national level through the benefits of the oil palm plantation and taxes, redistributed to society.

Further analysis of how benefits change hands in this case study, in which the investor is a local Indonesian company, is given in Table 8 . In case of a foreign investor, profits would be divided into a $43 \%$ foreign profit and a $41 \%$ national profit, for the non plasma scheme scenario. Therefore there is a clear change in hands of profits when a plantation is established on forested land. Profits from the local and global level are shifting to the national level, and to the foreign level in case of foreign investors. Biggest losers are local people and biggest winners are the plantation owners and the government of Indonesia through tax benefits.

An input output $(\mathrm{I} / \mathrm{O})$ model for palm oil industry in Papua can be found in Obidzinski et al. (2014). According to these authors, multiplying coefficients are in the range of $155 \%$ on the province economy. Comparing the results of the forests ecosystem services to the plantation without any escalation the benefits from the plantation are 2,153.00 USD ha ${ }^{-1} \mathrm{y}^{-1}$ and benefits from the forest ecosystem services $3,795.44$ USD ha $^{-1} \mathrm{y}^{-1}$, so the scenario of conserving the forest is still more benefitial, even when considering the $\mathrm{I} / \mathrm{O}$ effect of the plantation on the provincial economy.

\subsection{Emissions from forest to oil palm transformation in Indonesia}

Following the approach described in section 2.5, LUC emissions from forest conversion to oil palm in Indonesia in 2014, represented about $7.00 \%$ of total Indonesian emissions, $10.28 \%$ of Indonesian LUC emissions, and $0.35 \%$ of world emissions.

\section{Discussion}

\subsection{Oil palm LUC facts}

Plantation companies are seeking land for oil palm in Papua, as there is abundant and cheaper land very suitable for oil palm, due to abundant rain and high temperatures throughout the year (Prentice and Hope, 2005). If the palm oil companies are the ones making the profit and the local population receiving the problems and environmental cost due to the lost of ecosystem services then it could be argued that companies should compensate the local population. In the macroeconomic scale, consequences of deforestation are global, therefore, international monitoring and coaching as well as aid could be required to reverse deforestation practices.

Most of Indonesian Papua population still lives in rural areas and is dependent on the forests, as plantations are settled the people lose their traditional way to sustain themselves and they lack the education to re-convert to other occupations. Villages in Jayapura, are ruled by local leaders, and by local landlords who have rights over the local land. Their interests sometimes differ from those of the rest of the population. In our case study, landlords negotiated the conditions of the plantation and the benefits for the local population that include the plasma scheme.

The law in Indonesia supports conversion of forested land into other uses. According to Government of Indonesia (2010) conversion of convertible forest into other uses is allowed as long as in river areas there is still 30\% forest area remaining (Beehler and Marshall, 2007). predicted that by the end of the 21st century no lowland forests will remain in Papua. These forests constitute the end of the virgin primary forests left in Indonesia. Indonesia accounts for about $12 \%$ of world total plant species (Hanafi et al., 2013).

Corporations look for land that can be converted into very big plantations; they require huge extensions of land without geographical separation at the lowest possible price. Oil palm requires a lot of rain and high temperatures but is not very demanding for specific soil types (Pauli et al., 2014). Forests and peat land are suitable for oil palm plantation, but other available 


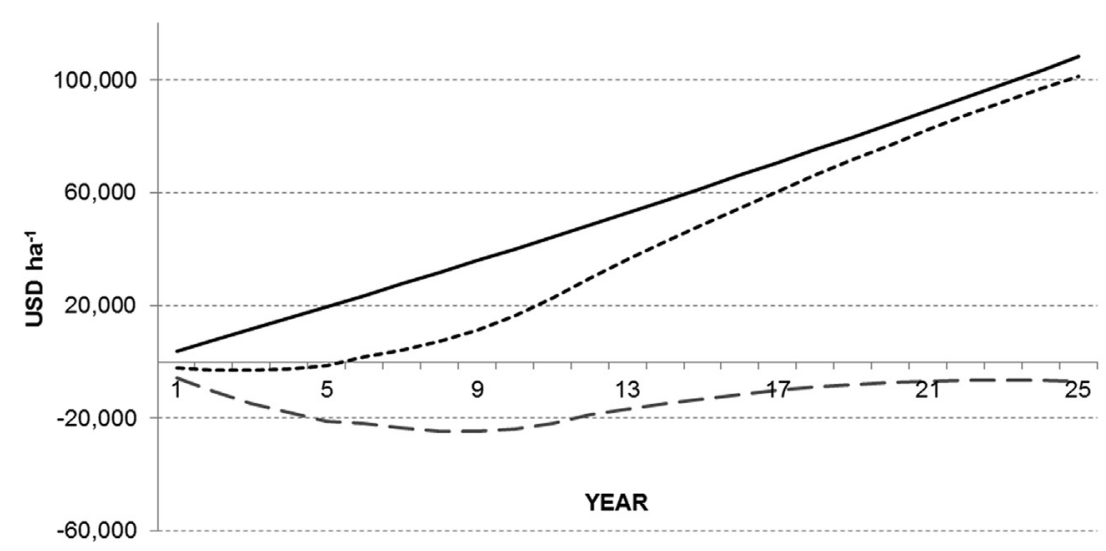

— Accumulated Total Benefits of Ecosystem Services

- Accumulated Benefits Commercial Plantation - Benefits Ecosystem Services

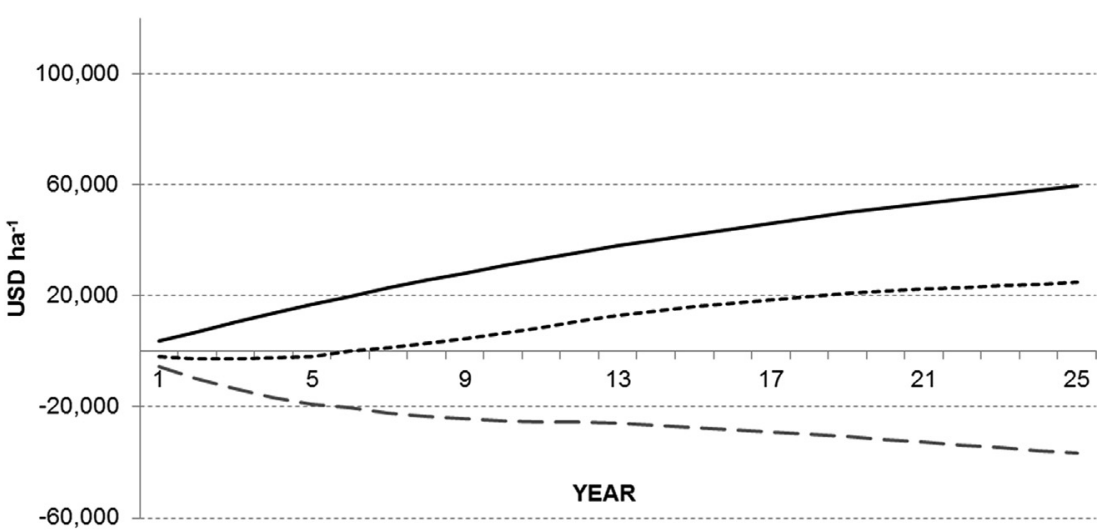

--- Discounted (10\%) Accumulated Commercial Plantation Earnings and (5\%) Social Plantation Benefits

-Discounted (5\%) Accumulated Total Benefits of Ecosystem Services

- Accumulated Benefits Plantation - Benefits Ecosystem Services

Fig. 10. Plantation and Forest discounted and non-discounted benefits.

Table 7

Summary of financial model results.

\begin{tabular}{ll}
\hline Commercial oil palm plantation versus Tropical forest in Papua & Value (USD ha ${ }^{-1}$ ) \\
\hline Commercial oil palm plantation & \\
$\quad$ Profit - 25 years cycle and 3\% increase in revenue prices and costs & $101,381.39$ \\
Average Yearly Profit - 3\% increase in revenue prices and costs & $4,055.26$ \\
NPV of Profit with 10\% Discount Rate & $24,782.78$ \\
Tropical forest & $108,229.42$ \\
$\quad$ Benefits with 1\% increase in ecosystem service value & $4,329.18$ \\
Average Yearly Profit - 1\% increase in ecosystem services value & $59,505.53$ \\
NPV of Profit/Cost with 5\% Discount Rate & $-6,848.06$ \\
Subtraction & -273.92 \\
$\quad$ Profit Plantation - Benefits Tropical Forest, 25 years cycle & $-34,722.75$ \\
Yearly Profit Plantation - Benefits Tropical Forest & \\
NPV of [Profit Plantation - Benefits Tropical Forest] &
\end{tabular}

and suitable land types can be used instead.

Environmental and customary rights and the right of indigenous communities are considered in Indonesian law (Government of Indonesia, 2009), but the fact is that not holding an ownership title over the land makes the local community have a weak position in front of the big palm oil corporations. In this work, during the site visit, human rights violation was not seen. Although many of the villagers opposed the plantation, they were in agreement with the status quo, as long as they were given a share of the profits from the plantation. They are trading the access to forest products, water and wellbeing provided by the forest, for social benefits, jobs or entrepreneurial opportunities at the oil palm plantation. In order for the population to accept the plantation, these new obtained benefits should be higher than the losses due to forest removal. 


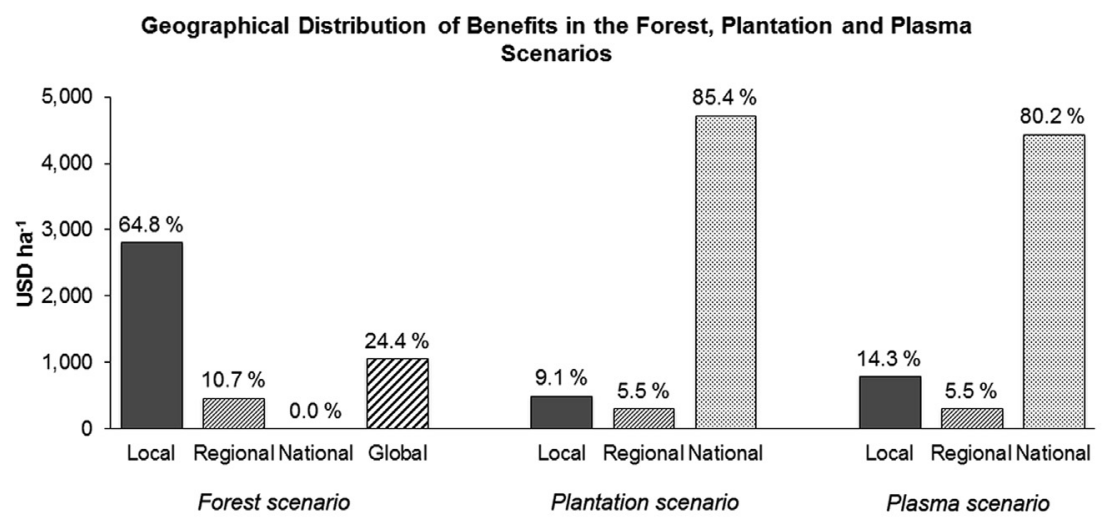

Profits Distribution by Category of Plantation and Plasma Scenarios

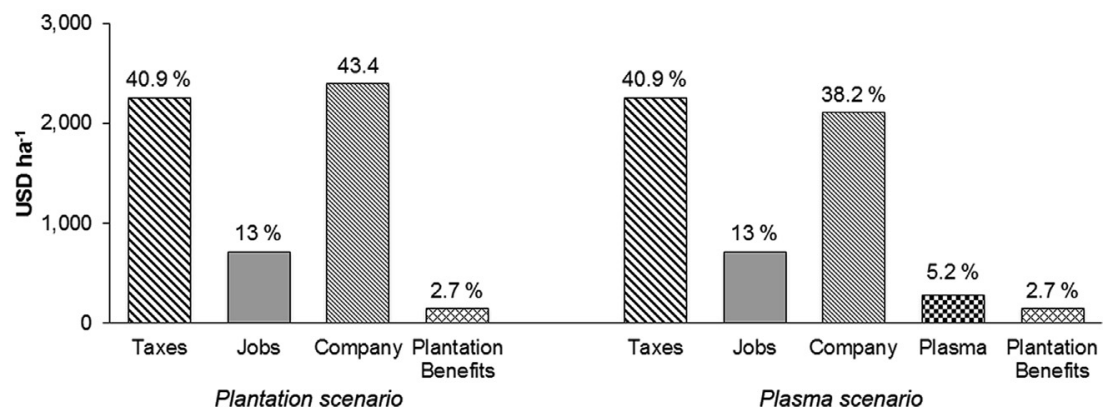

Fig. 11. Top: Geographical distribution of benefits. Bottom: Profits distribution by category of plantation and plasma Schemes.

Table 8

Winners and losers of the land use change. Summary table.

\begin{tabular}{|c|c|c|c|c|}
\hline Profit/(Cost) per area & USD ha $^{-1}$ & & & \\
\hline Local - Loss of ecosystem services & $-2,806.04$ & Biggest loser & $65 \%$ & of losses is for local people \\
\hline Local - Jobs and social benefits & 250.81 & & $5 \%$ & of profits \\
\hline Local - Taxes & 251.93 & & $5 \%$ & \\
\hline Regional - Loss of Ecosystem Services & -464.89 & Loser & $11 \%$ & of losses is for the region \\
\hline Regional - Jobs & 101.62 & & $2 \%$ & of profits \\
\hline Regional - Taxes & 205.19 & & $4 \%$ & \\
\hline National - Company & $2,400.90$ & Biggest winner & $43 \%$ & of profits is for Indonesia, or other country investor \\
\hline National - Jobs & 516.97 & & $9 \%$ & \\
\hline National - Taxes & $1,803.32$ & & $33 \%$ & of profits is for Indonesia, redistributed to Society \\
\hline Global - All Humanity & $-1,057.66$ & Big loser & $24 \%$ & of losses is for humanity \\
\hline
\end{tabular}

As the local indigenous population is very poor and not well educated, it is not difficult for corporations to settle agreements that give locals access to a better life, in exchange for the forest ecosystem services they enjoy. In our case study, the company had made an effort to employ local population and develop the plasma scheme. Environmentally, clearing had been conducted progresively and by mechanical means, but the fact of removing tropical forest was difficult to accept.

In view of the foregoing, it seems of particular importance the application of the concept of Social Cost of Carbon $\left(\mathrm{SC}-\mathrm{CO}_{2}\right)$; this is an economic metric intended to provide a comprehensive estimate of the net damages, the monetized value of the net impacts from the global climate change that results from the increase in $\mathrm{CO}_{2}$ emissions. According to estimates by the Global Change Interagency Working Group of the US Global Change Research Program (USGCRP) the SC-CO2 in the year 2020 for a 3\% discount rate would be 42 USD t $^{-1}$, emissions in 2007 USD (National Academies, 2017).

\subsection{Checking of feasibility}

4.2.1. First check - quantitative analysis (economics and emissions)

Economic feasibility assesment of each project should be required. The benefits obtained from the original land type scenario shall be compared to the economic benefits that the plantation renders. The change of forest to oil palm in this case study was found not economically feasible since the benefits of forest ecosystem services were higher than the ones of oil palm in most scenarios; i.e. conversion should not have been allowed.

Emissions of the original scenario should be compared to the emissions of the oil palm plantation. If the emissions of the oil palm plantation were found to be below the ones of the original scenario, the plantation in that particular location would be feasible. In case palm oil is used to produce biofuels, savings in emissions of the produced biodiesel shall be quantified, considering biodiesel production and land use change. If emissions from land use change are above zero the recommendation should be that the project is not 
approved; another land with less carbon stock shall be chosen instead. In general land with a $\mathrm{C}$ stock higher that oil palm (60-70 $\mathrm{tha}^{-1}$ ) should not be considered.

Total carbon stocks (above and below-ground biomass) of tropical forests in Malaysia were estimated in a wider range $\left(4-384 \mathrm{t} \mathrm{C} \mathrm{ha}^{-1}\right)$ than for oil palm plantations $\left(2-60 \mathrm{t} \mathrm{C} \mathrm{ha}^{-1}\right)$ (Kho and Jepsen, 2015). As a reference, the vegetation values assumed by the European Commission (2010) for oil palm and tropical rain forest in insular Asia are 60 and $230 \mathrm{tC} \mathrm{ha}^{-1}$. For tropical forest a loss of 623.3 tons of $\mathrm{CO}_{2}$ eq per ha $\left(\leftrightarrow 170 \mathrm{tC} \mathrm{ha}^{-1}\right)$ has been calculated in this work, assuming that the condition of the soil remains the same; if soil carbon stock is considered (mineral soil), about 153.72 tons of $\mathrm{CO}_{2}$ eq per ha have to be added up. In case of peat soil forest the loss would attain 832.75 tons of $\mathrm{CO}_{2}$ eq per ha. The amount of $\mathrm{CO}_{2 \text { eq }}$ saved by biodiesel was estimated at $3.73 \mathrm{tha}^{-1}$ (36\% savings above diesel produced from fossil fuel) (European Parliament, 2009), which means that for land use change from tropical forest to oil palm in mineral soil 167 years would be required to recover the emissions from LUC; for conversion of peat soil forest to oil palm, 223 years. These long recovery periods make LUC from tropical forest to oil palm unfeasible.

\subsubsection{Second check - qualitative analysis; benefits and losses from} LUC

For each project site both positive and negative effects of the oil palm plantation should be analyzed. In the present case study, the negative Impacts were loss of provisioning services, food, medicine, fuel, and timber from the forests. Loss of social services such as spiritual, wellbeing, meditation and a place for learning and teaching their kids. Also loss of regulating services, pollution of water courses, erosion, $\mathrm{CO}_{2}$ eq emissions. The positive impacts were jobs creation, entrepreneurship opportunities, infrastructure creation, regional growth, profits for the Indonesian society in the form of taxes, access to health, creation of small businesses, some upstream business generation for construction materials, a more diverse society with the arrival of workers from other parts of Indonesia.

\subsection{Incentives and compensation plan}

After the project feasibility check, a compensation plan for each case should be established in order to comply with the principle of fairness. The concept is that, when a project is proved to be feasible and it is undertaken, winners should compensate losers (Fig. 12). For instance, compensation for locals includes plasma, jobs, infrastructures, health and education. A survey shall be conducted, in order to identify the demands of the local population.

If the project is unfeasible it should be discontinued, and compensation channeled in order to conduct it in a feasible way. This is the scenario applicable to our case study.

\subsection{Regulatory measures}

One of the most important measures to avoid the loss of biodiversity as well as deforestation from land use change from forests and high biodiversity land to agricultural uses, particularly oil palm plantations, is to establish a land management plan for each region, and to identify the right places to plant oil palm, not only from the point of view of economics and crop requirements but also for environment protection, including carbon storage. According to Pacheco et al. (2011), seven biofuel sustainability standards (UE-RED, RTFO, RSB, RTRS, RSPO, FSC and SAN) have been developed. These certification agencies issue sustainability certificates based on their own criteria. They lack consensus on mitigation of impacts of indirect land use change. A standardized checking and monitoring system should be established through an independent agency. Certification shall be complemented by other mechanisms as effective land use planning.

\subsection{Recommendations}

At the time the field work was conducted the plantation under study was only 5,000 ha but it was expected to expand to a planned size of 28,000 ha. According to the results of this study, the first recommendation would be that the rest of the area granted for the plantation was not converted to oil palm. Another suitable land should be searched and a way to compensate the company for the price difference should be proposed. Oil palm plantations might be feasible in other areas that are not forested. Identification of areas without a high ecological and economic value would be required.

Survey results showed that the local population demanded the plantation company to share the profits, by giving them access to social services, fair jobs and access to the plasma scheme. Training the local population into the oil palm cultivation techniques is of

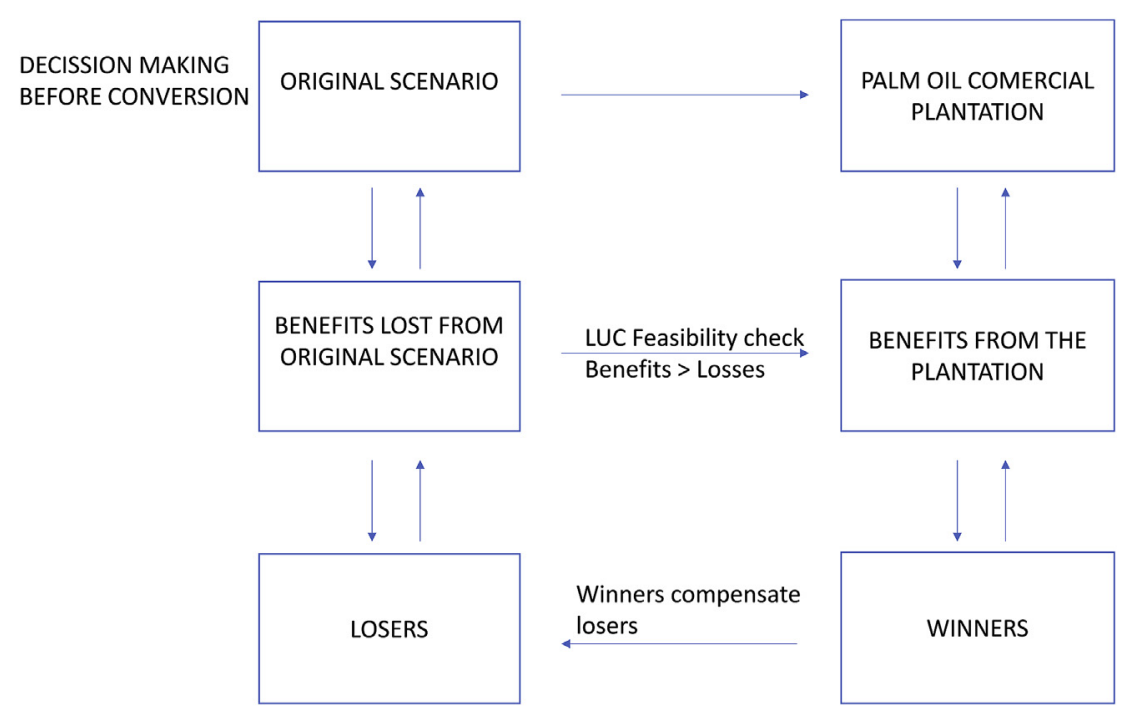

Fig. 12. Decision Making (Feasibility) diagram for feasible scenario. 
critical importance. Development is important for the region. Oil palm plantations should provide the local population with access to infrastructures, health and education. Access to electricity and potable water is very important for the local population. Other recommendations given by the local population are to avoid deforestation, fair land purchase, compensation for loss of forest ecosystem services and construction of downstream industries. Another issue that needs improvement is to involve the community in the process of negotiation and decision making, as they are the ones that suffer the consequences of the loss of forest and the access to the provisioning services they depend on for a living.

The plantation is not bringing the problems in itself, and it has been demonstrated to generate value. The problem is not to establish an oil palm plantation but to do it in forested land, due to loss of many ecosystem services in a local and global level. Other available lands could be used instead. Spatial plans and compensation programs are required to establish oil palm plantation in the right places.

\section{Conclusions}

This article tries to bring some light to the land use change problem of oil palm plantations in eastern provinces of Indonesia, where oil palm plantations establishment is still starting. They are being established on forested area and their feasibility needs to be assessed.

Results of this work showed that the benefits from Primary Forest Ecosystem Services are above the ones of palm oil; without using escalation and discount rates the forest benefits were $3,795.44$ USD ha ${ }^{-1} \mathrm{y}^{-1}$. Profits for the new established oil plantation amounted to 2,153.00 USD ha $\mathrm{y}^{-1}$. Therefore, the land use change was considered non-feasible from an economic point of view. Emissions due to land use change represented 623.3 tons of $\mathrm{CO}_{2}$ eq per ha following methodologies developed for the case that palm oil was used for biodiesel; it was estimated that 167 years would be needed to recover the emissions from forest conversion. Also, other important ecosystem services, some of them unique to Papua Island, are being lost.

Oil palm plantations generate value through the creation of jobs, entrepreneurship opportunities through the plasma scheme, creation of upstream and downstream industries and creation of infrastructures. Plantations, when established, should also bring additional benefits to the population such as access to health, education and profit sharing. Establishment of oil palm plantations in forested land has many negative consequences, due to loss of ecosystem services in a local and global level. Forests are very important for local people; they are their source of income, inspiration, freedom as well as leisure. Forests allow local population to live in a simple way. The plantation can bring economic benefits, but the loss of the forest cannot be replaced. Compensation to the local population by plantation companies should be greater than the benefits lost. Provision of social benefits, jobs and entrepreneurial opportunities shall be present in the conversion process of new plantations. Environmental impacts should be minimized.

In the process of conversion from primary forest to oil palm benefits are changing hands. Commercial plantations are feasible businesses; about $80 \%$ of the benefits from the oil palm plantation are shared by the investors and the Indonesian Government. The local population captures about $14 \%$ of the benefits in the form of health, education, infrastructures, plasma entrepreneurship opportunities and local jobs. The balance should be shifted towards the local population. Plantation companies should include social and environmental targets in their future strategy plans.

Forest ecosystem services are lost in the process of land transformation; about $65 \%$ of the losses are for the local population that loses access to the forest which represents their way of living. About $24 \%$ of the losses are lost at a global level mainly due to $\mathrm{CO}_{2}$ eq emissions from the loss of the carbon storage from the forest, loss of existence value and genetic material.

Economic, environmental and social feasibility check should be required for each new oil palm project. Independent international agencies, that monitor the feasibility of all new projects, should be established. Feasible projects investors shall compensate local population losing access to ecosystem services, and non-feasible projects shall be funded to be conducted in a feasible way. Other available lands could be used instead. Spatial plans and compensation programs shall be required to establish oil palm plantation in the right places. Above all, further research is required to determine the accurate values of the different ecosystem services in Papua; knowing the value would become an incentive for preservation.

\section{Acknowledgements}

The authors express their gratitude to participants in surveys and company staff that supplied data for this work. Many thanks to Mr. Meidy Rosano, our guide, translator and interpreter during our site visits to Papua. Many thanks to Mrs. Linda Go for translating the survey to Indonesian language. Grateful thanks to Matthew $\mathrm{H}$. Schauss and Edmund Keith for editing the paper. Grateful thanks to Prof. Emeritus J. Fernández for giving us the opportunity to conduct this study. Thanks are also given to Dr. Yolanda Lechón and Dr. Natalia Caldés for their support in the content of this article. This research did not receive any specific grant from funding agencies in a public, commercial or non-for-profit sector.

\section{References}

Abram, N.K., Meijaard, E., Wilson, K.A., Davis, J.T., Wells, J.A., Ancrenaz, M., Budiharta, S., Durrant, A., Fakhruzzi, A., Runting, R.K., Gaveau, D., Mengersen, K. 2017. Oil palm-community conflict mapping in Indonesia: a case for better community liaison in planning for development initiatives. Appl. Geogr. 78, 33-44. https://doi.org/10.1016/j.apgeog.2016.10.005.

Andrianto, A., Sedik, B.F., Waridjo, H., Komarudin, H., Obidzinski, K., 2014. The Impacts of Oil Palm Plantations on Forests and People in Papua: a Case Study from Boven Digoel District. CIFOR Working Paper.

Ansar, A., Flyvbjerg, B., Budzier, A., Lunn, D., 2017. Does infrastructure investment lead to economic growth or economic fragility? Evidence from China. https:// doi.org/10.1093/oxrep/grw022.

Bank of Indonesia, 2016. Monetary Policy Review. Economy, Monetary and Finance. June 2016

The ecology of Indonesia series. Volume VI. In: Beehler, B., Marshall, A. (Eds.), 2007. The Ecology of Papua. Part Two. Periplus.

Beukering, P.J.van, Cesar, H.S., Janssen, M.A., 2003. Economic valuation of the leuser national park on Sumatra, Indonesia economic valuation of the leuser national park on Sumatra, Indonesia. Ecol. Econ. 44, 43-62. https://doi.org/10.1016/ S0921-8009(02)00224-0.

Bloom, D.E., Canning, D., Sevilla, J., 2004. The effect of health on economic Growth . A Production Function Approach 32, 1-13. https://doi.org/10.1016/j.worlddev. 2003.07.002.

CAIT, 2018. Historic Greenhouse Gas Emissions [WWW Document]. URL. http://cait. wri.org/profile/Indonesia. (Accessed 25 May 2018).

Caroko, W., Komarudin, H., Obidzinski, K., Gunarso, P., 2011. Policy and Institutional Frameworks for the Development of Palm Oil-Based Biodiesel in Indonesia, vol. 62. CIFOR Working Paper.

de Groot, R., Brander, L., van der Ploeg, S., Costanza, R., Bernard, F., Braat, L., Christie, M., Crossman, N., Ghermandi, A., Hein, L., Hussain, S., Kumar, P., McVittie, A., Portela, R., Rodriguez, L.C., ten Brink, P., van Beukering, P., 2012. Global estimates of the value of ecosystems and their services in monetary units. Ecosyst. Serv. 1, 50-61. https://doi.org/10.1016/j.ecoser.2012.07.005.

Elkington, J., 1997. Cannibals with Forks: the Triple Bottom Line of 21st Century BUsiness. New Society Publishers. https://doi.org/0865713928.

European Commission, 2010. Commission Decision of 10 June 2010 on Guidelines for the Calculation of Land Carbon Stocks for the Purpose of Annex V to Directive 2009/28/EC.

European Parliament, 2009. Directive 2009/28/EC of the European Parliament and of the Council of 23 April 2009 on the Promotion of the Use of Energy from Renewable Sources and Amending and Subsequently Repealing.

European Parliament, 2018. Promotion of the Use of Energy from Renewable Sources ***I Amendments Adopted by the European Parliament on 17 January 2018 on the Proposal for a Directive of the European Parliament and of the 
Council on the Promotion of the Use of Energy from Renewable.

Glaser, B., Strauss, A., 1967. The Discovery of Grounded Theory: Strategies for Qualitative Research, First. ed.

Glauber, J., Gunawan, I., 2016. The Cost of Fire: An Economic Analysis of Indonesia's 2015 Fire Crisis. The World Bank.

Government of Indonesia, 2009. Environmental Protection and Management (Law No. 32/2009 dated October 3, 2009).

Government of Indonesia, 2010. The Procedure of Altering the Appropriation and Function of Forested Areas (Government Regulation No. 10/2010 Dated January 22,2010).

Gowdy, J., Howarth, R.B., Tisdell, C., 2010. Chapter 6 Discounting , ethics , and options for maintaining biodiversity and ecosystem integrity. In: The Ecological and Economic Foundations. The Economics of Ecosystems and Biodiversity, pp. $1-34$.

Hanafi, M., A, N., Fadia, Z., Nurbaiti, 2013. Indonesian country report on traditional medicine. In: International Conclave on Traditional Medicine, p. 21.

Hanushek, E., Wobmann, L., 2007. Education Quality and Economic Growth.

Indexmundi, 2016a. Crude Palm Oil Price [WWW Document]. Palm Oil HQ Lti Ltd. URL. $\quad$ https://www.indexmundi.com/commodities/?commodity=palmoil\&months $=60$. (Accessed 20 June 2007)

Indexmundi, 2016b. Palm Kernel Oil Price [WWW Document]. URL. https://www. indexmundi.com/commodities/?commodity=palm-kernel-oil\&months=60.

Indonesia, G.I.A. of, 2017. Identification of Islands and standardization of thei names. In: 11th United Nations Conference on the Standardization of Geographical Names.

Intergovernmental Panel on Climate Change, 2013. 2013 Supplement to the 2006 IPCC Guidelines for National Greenhouse Gas Inventories: Wetlands Task Force on National Greenhouse Gas Inventories. Intergovernmental Panel on Climate Change.

International Trade Centre, 2012. Palm Products Global Market Development, pp. 1-151.

Investments, Indonesia, 2017. Economic Growth Indonesia 2016 [WWW Document]. URL. https://www.indonesia-investments.com/news/todays-headlines/ economic-growth-indonesia-gdp-at-5.02-in-2016-not-good-not-bad/ item7587?. (Accessed 27 May 2018).

Irawan, S., Tacconi, L., Ring, I., 2013. Stakeholders' incentives for land-use change and REDD+: the case of Indonesia. Ecol. Econ. 87, 75-83. https://doi.org/10. 1016/j.ecolecon.2012.12.018.

IUCN, 2008. Summary of Species on the 2008 IUCN Red List.

Kho, L.K., Jepsen, M.R., 2015. Carbon stock of oil palm plantations and tropical forests in Malaysia: a review. Singapore J. Trop. Geogr. 36, 249-266. https://doi. org/10.1111/sjtg.12100.

Knoema, 2010. World Data Atlas Indonesia. GDP per capita Papua [WWW Document]. URL. https://knoema.com/atlas/Indonesia/Special-Region-of-Papua.

Luckow, P., Stanton, E.A., Fields, S., Ong, W., Biewald, B., Jackson, S., Fisher, J., 2016. Spring 2016 National Carbon Dioxide Price Forecast.

Man, E.L.Y., Baharum, A., 2011. A qualitative approach of identifying major cost influencing factors in palm oil mills and the relations towards production cost of Crude Palm Oil. Am. J. Appl. Sci. 8, 441-446. https://doi.org/10.3844/ajassp. 2011.441.446.

Meijaard, E., Garcia Ulloa, J., Sheil, D., Wich, S., Carlson, K., Juffer-Bignoli, D., Brooks, T., 2018. Oil Palm and Biodiversity. A Situation Analysis by the IUCN Oil Palm Task Force. https://doi.org/https://doi.org/10.2305/IUCN.CH.2018.11.en.

Ministry of Agriculture of Indonesia, 2013. Regulation of the Minister of Agriculture Number 98/Permentan/OT.140/9/2013.

Minsitry of Environment and Forestry Republic of Indonesia, 2018. The State of Indonesiás Forests 2018.

Moratilla, F.E., 2010. Valoración de los Activos Naturales de España. Ambient. La Rev. del Minist. Medio Ambient. ISSN 1577-9491, Nº. 91, 2010 (Ejemplar Dedic. a El valor la Biodiversidad). Idiom. español, pp. 76-92.

National Academies of Sciences Engineering and Medicine, 2017. Valuing Climate Damages. Updating Estimation of the Social Cost of Carbon Dioxide. https://doi. org/10.17226/24651.

Obidzinski, K., Andriani, R., Komarudi, H., Andrianto, A., 2012. Environmental and social impacts of oil palm plantations and their implications for biofuel production in Indonesia. Ecol. Soc. 17, 25. https://doi.org/https://doi.org/10. 5751/ES-04775-170125.

Obidzinski, K., Dermawan, A., Hadianto, A., 2014. Oil palm plantation investments in Indonesia's forest frontiers: limited economic multipliers and uncertain benefits for local communities. Environ. Dev. Sustain. 16, 1177-1196. https://doi.org 10.1007/s10668-014-9519-8.

Olschewski, R., Tscharntke, T., Benítez, P.C., Schwarze, S., Klein, A.M., 2006. Economic evaluation of pollination services comparing coffee landscapes in Ecuador and Indonesia. Ecol. Soc. 11. https://doi.org/10.1007/978-3-540-30290213.

Pacheco, P., German, L., van Gelder, J.W., Weinberger, K., Guariguata, M., 2011. Avoiding Deforestation in the Context of Biofuel Feedstock Expansion. An Analysis of the Effectiveness of Market-Based Instruments, p. 73.

Pascual, U., Muradian, R., Brander, L., Gomez-Baggethun, E., Martín-López, B., Verma, M., 2010. TEEB, Chapter 5: The economics of valuing ecosystem services and biodiversity. In: Kumar, Pushpam (Ed.), The Economics of Ecosystems and Biodiversity Ecological and Economic Foundations. Earthscan, London and Washington, pp. 1-133.

Pauli, N., Donough, C., Oberthür, T., Cock, J., Verdooren, R., Rahmadsyah Abdurrohim, G., Indrasuara, K., Lubis, A., Dolong, T., Pasuquin, J.M., 2014 Changes in soil quality indicators under oil palm plantations following application of "best management practices" in a four-year field trial. Agric. Ecosyst Environ. 195, 98-111. https://doi.org/10.1016/j.agee.2014.05.005.

Pearce, D., Moran, D., 1994. The Economic Value of Biodiversity. IUCN, EARTHSCAN, p. 104.

Porter, M.E., 1990. The competitive advantage of nations. Harv. Bus. Rev. 68, 21 https://doi.org/10.1007/978-1-349-11336-1.

Prentice, M., Hope, G., 2005. Climate of Papua. In: Ecology of Indonesian Papua Part vol. 1, pp. 176-195.

Price Waterhouse Coopers, 2010. Palm Oil Plantation. Industr Landscape, Regulatory and Financial Overview.

Svatonová, T., Herák, D., Kabutey, A., 2015. Financial profitability and sensitivity analysis of palm oil plantation in Indonesia. Acta Univ. Agric. Silvic. Mendelianae Brunensis 63, 1365-1373, https://doi.org/10.11118/actaun201563041365.

TEEB, 2009. The Economics of Ecosystems and Biodiversity for National and International Policy Makers.

The World Bank, 2009a. Investing in the Future of Papua \& West Papua. Infrastructure for Sustainable Development. How Can Infrastructure Contribute to Sustainable Development in Indonesia' S Most Remote Region?.

The World Bank, 2009b. Investing in the Future of Papua \& West Papua. Infrastructure for Sustainable Development.

The World Bank, 2015. World Development Indicators. Indonesia. GDP per capita PPP (current international \$) [WWW Document]. URL. https://data.worldbank. org/indicator/NY.GDP.PCAP.PP.CD. (Accessed 1 July 2017).

The World Bank, 2016a. Indonesian Demographics Data [WWW Document]. URL http://databank.worldbank.org/data/views/reports/reportwidget.aspx?Report_ Name $=$ CountryProfile $\& I d=b 450 f d 57 \&$ tbar $=\mathrm{y} \& d d=y \& i n f=$ n\&zm $=$ n\&country $=$ IDN. (Accessed 25 May 2018)

The World Bank, 2016b. Indonesia Population Data [WWW Document]. URL https://data.worldbank.org/indicator/SP.POP.TOTL?locations=ID. (Accessed 25 May 2018).

Triami Media, B.V., 2016. Historic Inflation Indonesia 2016 [WWW Document]. URL http://www.inflation.eu/inflation-rates/indonesia/historic-inflation/cpiinflation-indonesia.aspx. (Accessed 27 May 2018).

UNISDR, 2015. Global Assesment Report on Disaster Risk Reduction 2015. UNISDR

Vijay, V., Pimm, S.L., Jenkins, C.N., Smith, S.J., 2016. The impacts of oil palm on recent deforestation and biodiversity loss the impacts of oil palm on recent deforestation and biodiversity loss. PLoS One 1-19. https://doi.org/10.5061/dryad. $2 \mathrm{v} 77 \mathrm{j}$.

XE, n.d. Currency Exchange Historical Rates June 2016 [WWW Document]. URL https://www.xe.com/es/currencytables/?from=IDR\&date=2016-06-16 (accessed 6.16.2016)

Yayasan Pusaka, 2015. Papua Oil Palm Atlas: the Companies behind the Plantation Explosion, First. ed. (Jakarta). 